
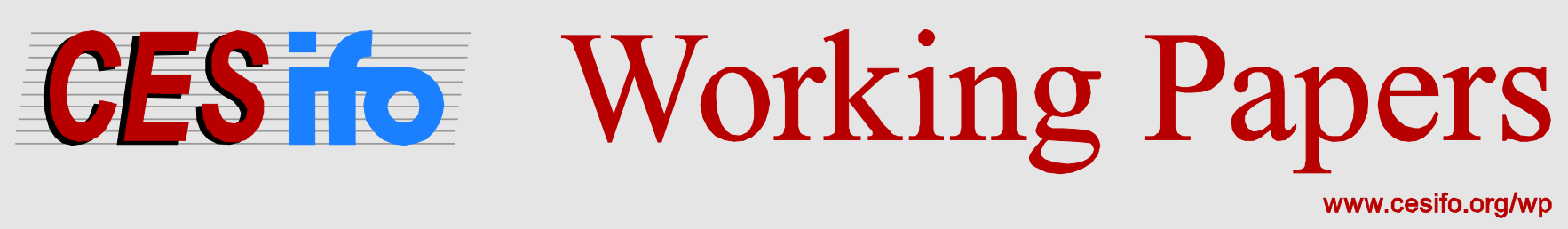

\title{
The Burden of Unanticipated Government Spending
}

\author{
Burkhard Heer \\ Christian Scharrer
}

\author{
CESIFO WORKING PAPER NO. 5876 \\ CATEGORY 6: FisCAL POLICY, MACROECONOMICS AND GROWTH \\ APRIL 2016
}

An electronic version of the paper may be downloaded

- from the SSRN website:

- from the RePEc website:

- from the CESifo website:

www.SSRN.com

Www.RePEc.org

www.CESifo-group.org/wp

ISSN 2364-1428 


\title{
The Burden of Unanticipated Government Spending
}

\begin{abstract}
We study the impact of a government spending shock on the distribution of income and wealth between cohorts in a dynamic stochastic Overlapping Generations model with two types of households, Ricardian households and rule-of-thumb consumers. We demonstrate that an unexpected increase in government spending increases income inequality and decreases wealth inequality. In contrast to the conventional wisdom that the financing of additional expenditures by debt rather than taxes especially burdens young generations, we find that a debt-financed increase in government spending also harms Ricardian households during retirement, while workers close to retirement benefit. The crucial element in our analysis is a wealth effect that results from the decline in the price of capital due to higher government debt.
\end{abstract}

JEL-Codes: E620, E300, E120, E240, D310.

Keywords: fiscal policy, debt financing, income and wealth distribution, rule-of-thumb consumers, Ricardian households, overlapping generations.

\author{
Burkhard Heer \\ University of Augsburg \\ Department of Economics \\ Universitätsstrasse 16 \\ Germany - 86159 Augsburg \\ burkhard.heer@wiwi.uni-augsburg.de
}

\author{
Christian Scharrer \\ University of Augsburg \\ Department of Economics \\ Universitätsstrasse 16 \\ Germany - 86159 Augsburg \\ christian.scharrer@wiwi.uni-augsburg.de
}

Date: April 25, 2016 


\section{Introduction}

The distributional consequences of higher government spending between different generations constitute a major concern for economy policy in modern industrialized countries. As a consequence of the demographic transition, the voters are greying and the economic well-being of older people becomes increasingly more important in the political decision-making process. Thus, it is quite likely that politicians are interested in imposing a considerably lower economic burden on older workers and retirees when they increase government spending. The appropriate fiscal rule, which controls the response of taxes and government debt if government consumption changes, plays a crucial role in this regard. A positive government spending shock financed by bonds transfers a real economic burden on present young or even future generations, whereas a tax-financed increase in government spending shifts the burden into the present. Therefore, it is generally believed that older workers prefer a higher government debt to higher taxes because they won't have to repay this debt and, for this reason, the politician will rather adopt a debt-financed increase in government spending in view of the aging voters.

Contrary to this conventional wisdom, we show that, to finance additional government spending, deferred taxation may also harm a large fraction of the elderly. For this reason, we consider a New Keynesian stochastic Overlapping Generations (OLG) model with two types of households, Ricardian households who save for old age and rule-of-thumb consumers who do not accumulate any wealth. ${ }^{1}$ In addition, we introduce an investment goods sector that results in a variable price of capital. In this setting, a debt-financed increase in government spending leads to a larger crowding-out effect on productive private investment than a tax-financed increase. The real price of capital decreases strongly and partially transmutes into an ad-

\footnotetext{
${ }^{1}$ Rule-of-thumb consumers have been prominently introduced in the business cycle analysis by Galí, Lopez-Salido, and Vallés (2007). They show that, in the presence of rule-of-thumb consumers, the standard New Keynesian model is able to replicate the empirical fact that private consumption rises in response to an unexpected increase in government consumption.
} 
ditional negative wealth shock affecting the wealth accumulation and consumption decisions of workers and retirees. Retired Ricardian households are completely exposed to this shock because they have accumulated considerable wealth and cannot increase their labor supply to benefit from higher wages. In contrast, young workers with little wealth and rule-of-thumb consumers suffer much less from debt financing of unexpected government expenditure. As a consequence of this wealth effect, the burden of a debt-financed increases in government spending is shifted mainly from the households with little wealth to the income-rich and wealth-rich households.

The main wealth channel in our model - higher government consumption crowds out capital and decreases the value of wealth - is supported by empirical evidence: 1) Over the life cycle, stocks play an important role in the accumulation of wealth in the US economy. From 2001 till 2007, the stock holdings share of total financial assets of families headed by a person between an age of 55 and 74 years exceeded a value of 50 percent in the United States as documented by Bricker, Dettling, Henriques, Hsu, Moore, Sabelhaus, Thompson, and Windle (2012). 2) Fiscal policy shocks have significant price effects on wealth. Agnello and Sousa (2013) estimate a panel vector autoregression model and provide empirical evidence for a sample of ten industrialized countries that a positive fiscal policy shock leads to an immediate and negative response of stock prices influencing the wealth of different cohorts.

Our New Keynesian model is broadly consistent with empirical evidence from VAR studies. In particular, an increase of government spending results in 1) an increase of output, ${ }^{2} 2$ ) private consumption, ${ }^{3} 3$ ) a strong decline in investment and the price

\footnotetext{
${ }^{2}$ Blanchard and Perotti (2002) provide evidence for the US postwar economy that GDP increases after an expansion of fiscal spending. Using panel structural VAR analysis from four industrialized countries, Ravn et al. (2012) also provide cross-country evidence for this hypothesis.

${ }^{3}$ There is some mixed evidence with regard to the effect of government consumption increases on private consumption. The prevalent view, however, indicates a positive effect of higher government consumption as in the studies presented by, for example, Blanchard and Perotti (2002), Galí et al. (2007), and Ravn et al. (2012).
} 
of capital, 4) higher employment, ${ }^{4} 5$ ) higher wages,${ }^{5}$ and 6) lower mark-ups. ${ }^{6}$ The presence of rule-of-thumb consumers helps to reconcile the model with the data and to effectuate the observed responses of output, employment, consumption, and wages. Since rule-of-thumb consumers are not subject to a wealth effect from higher government consumption, their labor supply curve shifts out less than that of the Ricardian households. As a consequence, there is more upward pressure on the real wage. In addition, higher wages allow for an increase of consumption. In the absence of rule-of-thumb consumers, we do not find an increase of aggregate private consumption in response to higher government spending.

In our model, we also introduce workers with different productivity types. Therefore, we are also able to model the empirically observed high concentration of wealth and the somewhat smaller concentration of income. The Gini coefficients of wealth and gross income in our model amount to 0.786 and 0.543 , respectively, which is broadly consistent with evidence presented by Budría Rodriguez, Díaz-Giménez, Quadrini, and Ríos-Rull (2002). ${ }^{7}$ Higher government consumption increases income inequality in our model since higher wages have a stronger incentive effect on the labor supply of the high-productivity workers than on the labor supply of low-productivity workers. ${ }^{8}$ In addition, the high-productivity workers are also the households with higher wealth and, for this reason, the accompanying effect of lower wealth prices also reinforce the rise in their labor supply. Wealth inequality declines with higher government

\footnotetext{
${ }^{4}$ See, for example, Blanchard and Perotti (2002).

${ }^{5}$ Here, again, the empirical evidence is mixed. Rotemberg and Woodford (1992) present evidence that real wages also increase after a government spending shock, while Monacelli et al. (2010) only find an statistically insignificant rise of the real wage for men.

${ }^{6}$ Again, Monacelli et al. (2010) only find evidence for a decline of the mark-ups that is statistically insignificant at the 95 percent confidence level.

${ }^{7}$ Budría Rodriguez et al. (2002) report Gini coefficients of (gross) wealth and income equal to 0.803 and 0.553 .

${ }^{8}$ Of course, this effect also depends on our assumption that the wage income is taxed linearly rather than progressively.
} 
consumption since the price of capital decreases. Therefore, the values of the existing wealth holdings decline, while it becomes more beneficial to build up savings for the less affluent younger cohorts.

Our work is most closely related to Brinca et al. (2016) who study the effects of wealth inequality and the average wealth level on fiscal multipliers. In a sample of 15 OECD countries, they find that fiscal multipliers increase with the country Gini of wealth and decrease with the capital-output ratio. The regression coefficients in their SVARs are quantitatively significant and an increase of one standard deviation in the wealth Gini raises the multiplier by about $17 \%$ of the average multiplier value. Similar to our model, their Overlapping Generations model is able to replicate the empirically observed heterogeneity in income and wealth. While Brinca et al. (2016) also include uncertainty with regard to idiosyncratic productivity, we focus on aggregate uncertainty in the form of stochastic government spending. In addition, we consider a New Keynesian model with sticky prices, while these authors abstract from any nominal friction. Therefore, our model is able to generate a positive response of private consumption to an increase in government consumption, while private consumption drops in the model of Brinca et al. (2016). In addition, these authors do not consider a variable price of capital that is central to our main result.

The rest of our paper is organized as follows: Section 2 describes and explains the OLG model. In Section 3, we calibrate the non-stochastic steady state of our model and explain the algorithm used for the numerical computation. In Section 4, we characterize the steady state and the associated distribution of consumption, income, wealth, and labor supply over the life-cycle. We show that a permanent rise of government spending increases income and decreases wealth inequality in the long run in our benchmark economy. Section 5 presents our main results with regard to the effects of an unanticipated temporary increase in government spending on the distribution of wealth and disposable income on the one hand and the welfare of the different cohorts, productivity types, and consumers (Ricardian versus rule-ofthumb consumers) on the other hand. We contrast the effects of a debt-financed government expenditures with those of tax-financed expenditures. In Section 6, we 
summarize and discuss the main findings of the paper and point out directions for future research.

\section{The Model}

We use an Overlapping Generations model with 240 generations and aggregate uncertainty. The period length is set to one quarter. Ricardian equivalence does not hold in our model so that the financing of government spending has real effects. The economy consists of households, firms, a government sector, and a monetary authority. We distinguish two types of households. The first kind of households which we name Ricardian households solves an inter-temporal maximization problem, while the second type behaves as a rule-of-thumb consumer. The firm sector is composed of three types of firms. A perfectly competitive firm produces a single final good and employs differentiated intermediate goods as inputs. These inputs are produced by a continuum of monopolistic competitive firms which use capital and labor in their production process. In addition, there is a capital producer who transforms investments (in terms of the final good) into new capital. The government both collects taxes and accidental bequests and issues risk-less bonds in order to finance its government purchases. The monetary authority monitors the inflation rate and sets the nominal interest rate according to a simple Taylor rule.

In the following, we present the model as follows. First, we describe the demographics. Next, we specify the production sectors of the economy which provides a rate of return on capital that depends on the utilization rate of capital $u_{t}$. The rate of return on capital is a composite of multiple rates since capital is first used in the production of the intermediate good (over the whole period $t$ ) before it is rented to the capital producers at the end of period $t$. Finally, we describe the behavior of the households who also choose the utilization rate of capital $u_{t}$ (see Christiano et al. $(2005))$. 


\subsection{Demographics}

Every period, a new cohort of constant size at age $s=1$ (corresponding to a real life age of 20) enters the economy. Households live at most $T=240$ quarters and each $s$-year old household faces a probability $\phi_{s}$ of surviving up to age $s+1$. More precisely, the parameter $\left(1-\phi_{s}\right)$ denotes the probability of dying at the end of age $s$. The number of living agents $\psi_{s, t}$ at age $s$ in period $t$ evolves according to the following formula:

$$
\psi_{s+1, t+1}=\phi_{s, t} \psi_{s, t},
$$

where $\phi_{0, t}$ is exogenously given. For simplification, we normalize the total number of living households $\sum_{s=1}^{T} \psi_{s, t}$ to one and assume that the composition of the population remains constant so that we can set $\psi_{s, t}=\psi_{s}$.

\section{$2.2 \quad$ Firms}

\subsubsection{Final Goods Firms}

There is a representative, perfectly competitive firm which produces a final good $Y_{t}$ using a constant returns to scale technology:

$$
Y_{t}=\left(\int_{0}^{1} Y_{j, t}^{(\epsilon-1) / \epsilon} \mathrm{d} j\right)^{\epsilon /(\epsilon-1)} .
$$

This firm assembles the imperfectly substitutable output $Y_{j, t}$ of intermediate producers and takes the price $P_{t}$ of the final good $Y_{t}$ as well as the prices $P_{j, t}$ of intermediary products as given. Moreover, $j \in[0,1]$, and $\epsilon$ denotes the price elasticity of demand for good $j$. After maximization of the profit function, $P_{t} Y_{t}-\int_{0}^{1} P_{j t} Y_{j, t} \mathrm{~d} j$, with respect to $Y_{j, t}$, we can derive the following demand function for intermediary goods:

$$
Y_{j, t}=\left(\frac{P_{j, t}}{P_{t}}\right)^{-\epsilon} Y_{t}
$$

Furthermore, the zero-profit condition in a perfectly competitive market implies

$$
P_{t}=\left(\int_{0}^{1} P_{j, t}^{1-\epsilon} \mathrm{d} j\right)^{1 /(1-\epsilon)} .
$$




\subsubsection{Intermediate Goods Firms}

The intermediate goods sector consists of a continuum of monopolistic firms indexed by $j \in[0,1]$. Each firm $j$ uses effective capital $u_{t} K_{j, t}$ and labor $N_{j, t}$ as input factors. The production technology is identical across firms and takes the form

$$
Y_{j, t}=N_{j, t}^{1-\alpha}\left(u_{t} K_{j, t}\right)^{\alpha}-F, \quad \alpha \in(0,1), F>0 .
$$

The constant $F$ denotes a fixed cost and can be considered as a loss of output in the production process. The utilization rate $u_{t}$ is considered exogenous by the firm and will be set by the Ricardian households who rent the capital stock (in efficiency units) to the firm (see also next section).

Each firm sets prices according to a Calvo (1983) mechanism. However, it is more appropriate to solve the firm's cost minimization problem first, where $r_{t}^{i s}$ is the real interest rate in the intermediate goods sector and $w_{t}$ is the real wage:

$$
\min _{u_{t} K_{j, t}, N_{j, t}} C_{j, t}=w_{t} N_{j, t}+r_{t}^{i s} u_{t} K_{j, t} \text { s.t. } Y_{j, t}=N_{j, t}^{1-\alpha}\left(u_{t} K_{j, t}\right)^{\alpha}-F .
$$

The first order conditions of this cost-minimization problem with respect to $N_{j, t}$ and $u_{t} K_{j, t}$ are presented by:

$$
\begin{aligned}
& w_{t}=(1-\alpha) g_{j, t}\left(\frac{u_{t} K_{j, t}}{N_{j, t}}\right)^{\alpha}, \\
& r_{t}^{i s}=\alpha g_{j, t}\left(\frac{u_{t} K_{j, t}}{N_{j, t}}\right)^{\alpha-1},
\end{aligned}
$$

where $g_{j, t}$ denotes the Lagrange multiplier which also describes the real marginal cost of production. Moreover, since we assume that the production of $Y_{j, t}+F$ is characterized by a constant returns to scale technology, the variable $g_{j, t}$ also equals the variable unit costs of production. The first order conditions (6a) and (6b) imply that marginal costs are equal across all firms, since every firm uses the same capitallabor ratio. Thus, we can drop the index $j, g_{t}=g_{j t}$ for all $j \in[0,1]$.

Price setting. Firms choose their optimal nominal prices in a staggered fashion, according to Calvo (1983). There are two types of firms. The first type $A$ sets their optimal relative price by solving an inter-temporal profit optimization problem, 
whereas type $N$ firms are only allowed to adjust their price in period $t$ according to a simple rule of thumb:

$$
P_{N, t+1}=\pi P_{N, t}
$$

where $\pi$ denotes the stationary value of the inflation factor. ${ }^{9}$ The probability of being a firm of type $A$ in period $t$ is given by $(1-\varphi)$. The description of the optimal price setting is delegated to the Appendix A.1.

Real Wage Rigidity. Following the approach of Blanchard and Galí (2007) and Uhlig (2007), we introduce a real wage rigidity

$$
w_{t}=\left(w_{t-1}\right)^{\mu}\left(w_{t}^{f}\right)^{1-\mu}
$$

where $\mu \geq 0$ and the term $w_{t}^{f}$ denotes the marginal rate of substitution between consumption and hours.

\subsubsection{Capital Producers}

In the following, we introduce capital adjustment costs in the model so that the price of capital in units of the final goods is variable. By this device, we are able to study the impact of government financing on capital prices and, hence, individual wealth. To keep the model tractable, adjustment costs accrue in a separate capital production sector rather than at the individual household level. For this reason, we assume a representative perfectly competitive firm that faces the following demand for newly installed capital:

$$
I_{t}=K_{t+1}-(1-\delta) K_{t}
$$

The variables $K_{t}$ and $I_{t}$ denote the existing aggregate capital stock and aggregate investment and both variables are expressed in terms of the final good. The produc-

\footnotetext{
${ }^{9}$ Here and in the following, we express stationary variables without a time index.
} 
tion of the investment good is described by the following technology:

$$
I_{t}=f\left(I_{t}^{D} / K_{t}\right) K_{t}
$$

with

$$
f\left(I_{t}^{D} / K_{t}\right)= \begin{cases}\frac{a_{1}}{1-\zeta}\left(\frac{I_{t}^{D}}{K_{t}}\right)^{1-\zeta}+a_{2}, & \text { for } 1 \neq \zeta>0 \\ a_{1} \ln \left(\frac{I_{t}^{D}}{K_{t}}\right)+a_{2}, & \text { for } \zeta=1 .\end{cases}
$$

The variable $I_{t}^{D}$ denotes the demand for final goods as input factors in the production process of $I_{t}$. The capital producers sell the investment goods at the price $q_{t}$ and rent capital at the rate $r_{t}^{c s}$ so that profits of capital producers $\Omega_{t}^{c}$ are given by:

$$
\max _{I_{t}^{D}, K_{t}} \Omega_{t}^{c}=q_{t} f\left(I_{t}^{D} / K_{t}\right) K_{t}-I_{t}^{D}-r_{t}^{c s} K_{t}
$$

Profit maximization of the capital producers with respect to $I_{t}^{D}$ and $K_{t}$ results in the following first-order conditions:

$$
\begin{aligned}
q_{t} & =\frac{1}{f^{\prime}\left(I_{t}^{D} / K_{t}\right)}=\frac{1}{a_{1}}\left(\frac{I_{t}^{D}}{K_{t}}\right)^{\zeta}, \\
r_{t}^{c s} & =q_{t}\left(f\left(I_{t}^{D} / K_{t}\right)-f^{\prime}\left(I_{t}^{D} / K_{t}\right) \frac{I_{t}^{D}}{K_{t}}\right) .
\end{aligned}
$$

In equilibrium, profits are equal to zero, $\Omega_{t}^{c}=0 .{ }^{10}$

\subsection{Households}

The households supply labor in the first $T_{w}=160$ periods and retire during the remaining $T_{r}=80$ periods of their life. Every newborn generation consists of $v_{R o T} \psi_{1}$ rule-of-thumb (RoT) consumers that have no access to financial markets over the life-cycle ${ }^{11}$ and $\left(1-v_{R o T}\right) \psi_{1}$ Ricardian households, where the fraction $v_{R o T}$ of rule-

\footnotetext{
${ }^{10}$ See Appendix A.1.

${ }^{11}$ The behavior of the rule-of-thumb consumers can be justified by a lack of access to financial markets, binding borrowing constraints, myopia, or simply no interest in inter-temporal trading. We follow Gali, Lopez-Salido, and Javier (2007).
} 
of-thumb-consumers is exogenously given. The household does not change its type over the life-cycle.

In addition to their consumption behavior, households also differ with respect to their idiosyncratic productivity level $e_{j}^{s}$ that depends on the productivity type $j \in$ $\{1,2,3\}$ and age $s$. We assume that the share $v_{j}$ of the productivity type $j$ remains constant in each cohort and that a household does not change its productivity type $j$ over the life-cycle. As a consequence, the wage income in period $t$ of the Ricardian household, for example, is given by $\left(1-\tau_{t}^{w}\right) w_{t} e_{j}^{s} n_{t, j}^{s}$, where $w_{t}$ and $n_{t, j}^{s}$ denote the wage rate per efficiency unit and the labor supply of the $s$-year-old Ricardian household with productivity type $j$ in period $t$. Wages are taxed at the rate $\tau_{t}^{w}$.

We describe the behavior of Ricardian and rule-of-thumb households in turn.

\subsubsection{Ricardian Households}

The Ricardian household with productivity type $j \in\{1,2,3\}$ maximizes the following discounted expected lifetime utility at the beginning of period $t$ :

$$
U_{t, j}=E_{t} \sum_{s=1}^{T} \beta^{s-1}\left(\prod_{j=1}^{s} \phi_{j-1}\right) u\left(c_{t+s-1, j}^{s}, n_{t+s-1, j}^{s}\right) .
$$

Instantaneous utility $u\left(c_{t, j}^{s}, n_{t, j}^{s}\right)$ is a function of consumption $c_{t, j}^{s}$ and labor $n_{t, j}^{s}$ :

$$
u\left(c_{t, j}^{s}, n_{t, j}^{s}\right)=\frac{\left(c_{t, j}^{s}\right)^{1-\eta}-1}{1-\eta}-\gamma_{0} \frac{\left(n_{t, j}^{s}\right)^{1+\gamma}}{1+\gamma},
$$

where $1 / \eta$ and $1 / \gamma$ denote the intertemporal elasticity of substitution and the Frisch labor supply elasticity, respectively. For the retired household, $s>T_{w}$, labor supply is equal to zero, $n_{t, j}^{s} \equiv 0$.

The Ricardian household with productivity type $j$ holds two kinds of assets, capital stock $k_{t, j}^{s}$ and government bonds $b_{t, j}^{s}$. Furthermore, we assume that the initial endowment with assets is zero at age $s=1, k_{t, j}^{1}=b_{t, j}^{1}=0$. Let $q_{t}$ denote the price of capital. The capital stock $k_{t}^{s}$ yields the real return $r_{t}$ and depreciates at rate $\delta$ :

$$
R_{t}=1+r_{t}=1+r_{t}^{i s} u_{t}+r_{t}^{c s}-\delta\left(u_{t}\right) q_{t}+\frac{\Omega_{t}}{K_{t}}
$$


The total return on capital is a composite of multiple returns. We assume that the household first lends his capital stock in efficiency units, $u_{t} k_{t, j}^{s}$, to the intermediate goods firms over the period $t$. At the beginning of period $t$, the household also decides about the utilization rate $u_{t} \cdot{ }^{12}$ At the end of the period $t$, the intermediate goods firms pay the return $r_{t}^{i s}$ to the household and capital depreciates at the rate $\delta$ depending on the utilization rate $u_{t}$ :

$$
\delta\left(u_{t}\right)=\delta_{0}+\delta_{1} u_{t}^{1+\epsilon_{u}}
$$

where $\epsilon_{u}$ is the elasticity of the depreciation rate with respect to the utilization rate. The parameters $\delta_{0}$ and $\delta_{1}$ are positive constants. Since the value of the capital amounts to $q_{t} k_{t, j}^{s}$, the depreciation cost per unit of capital amounts to $\delta\left(u_{t}\right) q_{t}$. In addition, capital owners receive their share in total profits in the intermediate goods sector $\frac{\Omega_{t}}{K_{t}} k_{t, j}^{s}$, where $K_{t}$ denotes aggregate capital. Subsequently, the household lends the capital stock to the capital goods producers and earns the interest $r_{t}^{c s}$.

The term $R_{t}^{b}$ describes the nominal gross interest rate on bonds. Hence, the price of government bonds $b_{t+1, j}^{s}$ is denoted by $1 / R_{t}^{b}$ so that total assets of the individual Ricardian households with productivity type $j$ and age $s$ are presented by:

$$
a_{t+1, j}^{s+1} \equiv q_{t} k_{t+1, j}^{s+1}+\frac{b_{t+1, j}^{s+1}}{R_{t}^{b}} .
$$

Let $A_{t+1}=q_{t} K_{t+1}+\frac{B_{t+1}}{R_{t}^{b}}$ and $\chi_{t+1}$ denote total assets and the fraction of bond holdings in total assets, respectively, with:

$$
\chi_{t+1}=\frac{B_{t+1} / R_{t}^{b}}{A_{t+1}} .
$$

Since both assets will yield the same expected return in equilibrium, the household will be indifferent with respect to his portfolio allocation on government bonds $b_{t, j}^{s}$ and capital $k_{t, j}^{s}$. We, therefore, assume that all Ricardian households hold these two

\footnotetext{
${ }^{12}$ Since the first-order conditions of the households with respect to the utilization rate are identical and imply the same utilization rate for all households, we drop the indices $j$ and $s$ from the utilization rate $u_{t, j}^{s}$.
} 
assets in the same proportion implying:

$$
\begin{aligned}
b_{t, j}^{s} & =R_{t}^{b} \chi_{t} a_{t}^{s}, \\
k_{t, j}^{s} & =\frac{\left(1-\chi_{t}\right)}{q_{t}} a_{t}^{s} .
\end{aligned}
$$

Accordingly, the budget constraint of the $s$-year old Ricardian household with productivity type $j$ in period $t$ is presented by:

$$
\begin{aligned}
\left(1+\tau^{c}\right) c_{t, j}^{s}+a_{t+1, j}^{s+1}= & \left(1-\tau_{t}^{w}\right) w_{t} e_{j}^{s} n_{t, j}^{s}+\left(q_{t}+\left(1-\tau_{t}^{k}\right) r_{t}\right) k_{t, j}^{s} \\
& +\frac{b_{t, j}^{s}}{\pi_{t}}+t_{t}+\text { pens }_{t, j}
\end{aligned}
$$

where $\tau_{t}^{c}$ and $\tau_{t}^{k}$ denote the consumption and capital income tax rates in period t. In addition to his labor and capital income, the household receives lump-sum transfers $t r_{t}$ and pensions $p e n_{t, j}^{s}$. Pensions are only paid to retired agents, $s>T_{w}$, and depend on the productivity type $j$. The public pay-as-you-go pension scheme will be described in more detail below. The first order-conditions are as follows:

$$
\begin{aligned}
\left(c_{t, j}^{s}\right)^{-\eta} & =\lambda_{t, j}^{s}\left(1+\tau^{c}\right) \\
\gamma_{0}\left(n_{t, j}^{s}\right)^{\gamma} & =\lambda_{t, j}^{s}\left(1-\tau_{t}^{w}\right) w_{t}^{f} e_{j}^{s}, \\
\lambda_{t, j}^{s} & =\beta \phi_{s} E_{t}\left\{\lambda_{t+1, j}^{s+1} \frac{\left(q_{t+1}+\left(1-\tau_{t+1}^{k}\right) r_{t+1}\right)}{q_{t}}\right\}, \\
\lambda_{t, j}^{s} & =\beta \phi_{s} E_{t}\left\{\lambda_{t+1, j}^{s+1}\left(\frac{1+r_{t}^{b}}{\pi_{t+1}}\right)\right\}, \\
r_{t}^{i s} & =q_{t} \frac{\partial \delta\left(u_{t}\right)}{\partial u_{t}},
\end{aligned}
$$

with $r_{t}^{b} \equiv R_{t}^{b}-1$

\subsubsection{Rule-of-Thumb Consumers}

The $s$-year old rule-of-thumb consumers with productivity type $j \in\{1,2,3\}$ do not save. They maximize instantaneous utility in every period $t$ :

$$
u\left(c_{t, j}^{s, R o T}, n_{t, j}^{s, R o T}\right)=\frac{\left(c_{t, j}^{s, R o T}\right)^{1-\eta}-1}{1-\eta}-\gamma_{0} \frac{\left(n_{t, j}^{s, R o T}\right)^{1+\gamma}}{1+\gamma} .
$$


subject to the budget constraint

$$
\left(1+\tau^{c}\right) c_{t, j}^{s, R o T}=\left(1-\tau_{t}^{w}\right) w_{t} e_{j}^{s} n_{t, j}^{s, R o T}+t r_{t}+p e n s_{t, j}
$$

where $c_{t, j}^{s, R o T}$ and $n_{t, j}^{s, R o T}$ denote consumption and labor supply of rule-of-thumb con-

sumers, respectively. The first-order conditions with respect to $c_{t, j}^{s, R o T}$ and $n_{t, j}^{s, R o T}$ are represented by:

$$
\begin{aligned}
\left(c_{t, j}^{s, R o T}\right)^{-\eta} & =\lambda_{t, j}^{s}\left(1+\tau^{c}\right) \\
\gamma_{0}\left(n_{t, j}^{s, R o T}\right)^{\gamma} & =\lambda_{t, j}^{s}\left(1-\tau_{t}^{w}\right) w_{t}^{f} e_{j}^{s} .
\end{aligned}
$$

\subsection{Government Sector}

\subsubsection{Government Budget}

In the following sections, we aim to study the allocative, distributive, and welfare effects of a change in government consumption $G_{t}$. For this reason, we assume that government expenditures are exogenous and follow an AR(1) process:

$$
\ln \left(\frac{G_{t}}{G}\right)=\rho_{g} \ln \left(\frac{G_{t-1}}{G}\right)+\epsilon_{t}
$$

where $\epsilon_{t} \sim N\left(0, \sigma_{g}^{2}\right)$ and $G$ denotes the non-stochastic steady state value of government consumption. In addition, the government spends the amount $T r_{t}$ on transfers which are assumed to be constant, $\operatorname{Tr}_{t} \equiv \operatorname{Tr}=\theta_{t r} Y$. The parameter $\theta_{t r}$ denotes the share of aggregate transfers to GDP. Furthermore, aggregate transfers $\operatorname{Tr}_{t}$ are always equal to individual transfers $t r_{t}$ since the total population is normalized to one.

Government expenditures are financed by taxes $\Psi_{t}$, debt, $B_{t+1} /\left(R_{t}^{b}\right)-B_{t} / \pi_{t}$, and confiscated accidental bequests $B e q_{t},{ }^{13}$ so that the government budget is presented

\footnotetext{
${ }^{13}$ Our results are insensitive with regard to the assumption that accidental bequests are used as government revenues in the government budget constraint. Alternatively, we could have assumed perfect annuity markets. In this case, the resulting consumption-age profile would be increasing
} 
by:

$$
\frac{B_{t+1}}{R_{t}^{b}}=\operatorname{Tr}_{t}+\frac{B_{t}}{\pi_{t}}+G_{t}-\Psi_{t}-B e q_{t}
$$

The labor income tax $\tau_{t}^{w}$ is composed of a payroll tax $\tau_{t}^{G}$ and a social security contribution $\tau_{t}^{p}$ :

$$
\tau_{t}^{w}=\tau_{t}^{G}+\tau_{t}^{p}
$$

so that the fiscal authority only collects $\tau_{t}^{G}$. Therefore, total tax revenues $\Psi_{t}$ from consumption, the payroll tax, and capital income amount to:

$$
\Psi_{t}=w_{t} \tau_{t}^{G} N_{t}+\tau_{t}^{k} r_{t} K_{t}+\tau^{c} C_{t}
$$

We follow Gali et al. (2007) and assume that the government adjusts its tax revenues to a change in government spending and debt according to the fiscal rule:

$$
\frac{\left(\Psi_{t}-\Psi\right)}{Y}=\omega_{g} \frac{\left(G_{t}-G\right)}{Y}+\omega_{b} \frac{\left(B_{t} / \pi_{t}-B\right)}{Y},
$$

where $\omega_{G}$ and $\omega_{b}$ are positive constants that control the dynamics of tax revenues. In order to implement this fiscal rule, we assume that the government increases its tax on labor and capital income, $\tau_{t}^{G}$ and $\tau_{t}^{k}$, and that, in accordance with empirical evidence for the US economy, the two income tax rates $\tau_{t}^{w}$ and $\tau_{t}^{k}$ are related by the following linear equation: ${ }^{14}$

$$
\tau_{t}^{k}=\beta_{0}^{k}+\beta_{1}^{k} \tau_{t}^{w}
$$

over the entire life-cycle as also demonstrated by Hansen and İmrohoroğlu (2008); this behavior, however, would be in contradiction to empirical findings of Fernández-Villaverde and Krueger (2007).

${ }^{14}$ In Appendix A.4, we graph the two tax rates for the US economy during 1985-2008. The correlation coefficient of these two tax rates amounts to 0.32 . 


\subsubsection{Social Security}

The social security authority collects contributions from workers to finance its pension payments to the retired agents. For simplification, we assume that pensions are constant over time. The individual pensions pen $_{t, j}$ for productivity types $j \in\{1,2,3\}$ amount to

$$
\operatorname{pen}_{t, j}=\operatorname{pen}_{j}=\operatorname{rep}\left(1-\tau^{P}-\tau_{t}^{G}\right) w \bar{n}_{j}
$$

where rep denotes the net replacement ratio with respect to wage income. The individual pension depends on the productivity type $j$ of the household through the average efficient labor supply $\bar{n}_{j}$ in group $j:{ }^{15}$

$$
\bar{n}_{j}=\frac{\sum_{s=1}^{T_{w}} \psi_{s} v_{j} e_{j}^{s}\left(v_{R o T} n_{j}^{s}+\left(1-v_{R o T}\right) n_{j}^{s, R o T}\right)}{\sum_{s=1}^{T_{w}} \psi_{s} v_{j}} .
$$

In equilibrium, the budget of the social security authority is balanced:

$$
\sum_{j=1}^{3}\left(\sum_{s=T_{w}+1}^{T} \psi_{s} v_{j} \text { pen } n_{j}\right)=w_{t} \tau_{t}^{p} N_{t}
$$

where $N_{t}$ denotes aggregate efficient labor that will be defined below.

\subsection{Central Bank}

The monetary regime sets the nominal gross interest rate $R_{t}^{b}$ according to a simple Taylor rule:

$$
\ln \left(\frac{R_{t}^{b}}{R^{b}}\right)=\phi_{m} \ln \left(\frac{R_{t-1}^{b}}{R^{b}}\right)+\left(1-\phi_{m}\right) \phi_{\pi} \ln \left(\frac{\pi_{t}}{\pi}\right),
$$

where $\phi_{m}$ controls the degree of interest rate smoothing and $\phi_{\pi}>1$ represents the response coefficient for inflation. The variables $R^{b}$ and $\pi$ denote the nominal gross interest rate and the inflation factor in the non-stochastic steady state.

\footnotetext{
${ }^{15}$ For simplification, we assume that pensions do not depend on past contributions and do not depend on whether the household is Ricardian or a rule-of-thumb consumer.
} 


\subsection{Equilibrium Conditions}

In equilibrium, aggregate variables are equal to the sum of the individual variables:

$$
\begin{aligned}
K_{t+1}= & \sum_{s=2}^{T} \sum_{j=1}^{3}\left(1-v_{R o T}\right) \psi_{s-1} v_{j} k_{t+1, j}^{s} \\
I_{t}= & \sum_{s=2}^{T} \sum_{j=1}^{3}\left(1-v_{R o T}\right) v_{j}\left[\psi_{s} k_{t+1, j}^{s+1}-\left(1-\delta\left(u_{t}\right)\right) \psi_{s-1} v_{j} k_{t, j}^{s}\right] \\
B_{t}= & \sum_{s=2}^{T} \sum_{j=1}^{3}\left(1-v_{R o T}\right) \psi_{s-1} v_{j} b_{t, j}^{s}, \\
N_{t}= & \sum_{s=1}^{T} \sum_{j=1}^{3} \psi_{s} v_{j} e_{j}^{s}\left[\left(1-v_{R o T}\right) n_{t, j}^{s}+v_{R o T} n_{t, j}^{s, R o T}\right] \\
C_{t}= & \sum_{s=1}^{T} \sum_{j=1}^{3} \psi_{s} v_{j}\left[\left(1-v_{R o T}\right) c_{t, j}^{s}+v_{R o T} c_{t, j}^{s, R o T}\right] \\
B e q_{t+1}= & \sum_{s=2}^{T} \sum_{j=1}^{3}\left(1-v_{R o T}\right) \psi_{s-1} v_{j}\left(1-\phi_{s-1}\right)\left[\frac{b_{t+1, j}^{s}}{\pi_{t+1}}+\right. \\
& \left.+\left(\left(1-\tau_{t+1}^{k}\right) r_{t+1}+q_{t+1}\right) k_{t+1, j}^{s}\right] .
\end{aligned}
$$

Profits in the capital producer sector are equal to zero, $\Omega_{t}^{c}=0$, and the aggregate resource constraint is given by:

$$
Y_{t}=I_{t}^{d}+C_{t}+G_{t}
$$

\section{Calibration}

Since we are interested in the short run effects of an unanticipated government spending shock, we calibrate the model on a quarterly basis and linearize the model around a steady state with zero inflation by using the methods described in Chapters 10.2.1 in Heer and Maußner (2009). Most of our parameters are standard in the RBC/DSGE literature and are summarized in Table 1.

Production. With regard to the production technology, we pick a standard value of $\alpha=0.36$ for the production elasticity of capital. We set the utilization rate $u$ 


\begin{tabular}{|l|llll|}
\hline Production: & $\alpha=0.36$ & $\delta=0.025$ & $\epsilon=6$ & $\varphi=0.75$ \\
& $\zeta=1$ & $q=1$ & $\epsilon_{u}=1$ & $u=1$ \\
\hline Demographics: & $T=240$ & $T_{w}=160$ & $T_{r}=80$ & $v_{R o T}=0.43$ \\
\hline Households: & $\beta=1.004$ & $\eta=2$ & $\gamma_{0}=1650$ & $\gamma=5$ \\
& $\mu=0.8$ & & & \\
\hline Government & $G / Y=20 \%$ & $\rho_{g}=0.87$ & $\sigma_{g}=0.016$ & $\omega_{g}=0.1$ \\
\& PAYG: & $\omega_{b}=0.33$ & $\tau^{c}=0.05$ & $r e p=0.45$ & $\beta_{0}^{k}=0.20$ \\
& $\beta_{1}^{k}=0.58$ & $\theta_{t r}=6.6 \%$ & $B / Y=0$ & \\
\hline Central bank: & $\phi_{m}=0.9$ & $\phi_{\pi}=1.1$ & $\pi=1$ & \\
\hline
\end{tabular}

Table 1: Quarterly Parameterization of the OLG model

equal to 1 in the steady state of our model and determine the parameters $\delta_{0}$ and $\delta_{1}$ such that the depreciation rate $\delta$ is equal to 0.025 . The parameter $\zeta$ from the capital adjustment cost function (11) is set to 1 following Galí et al. (2007). In addition, we report results for the case $\zeta=0$, where adjustment costs of capital play no role in the transmission of fiscal policy. We choose a standard value for the price elasticity equal to $\epsilon=6$ implying a gross price markup of 1.2 in the steady state, where the degree of price stickiness $\varphi$ is set to 0.75 . Moreover, we assume that aggregate profits are equal to zero in the steady state in order to calibrate the fixed costs $F$. Finally, our calibration of the elasticity $\epsilon_{u}$ of the change in the depreciation rate with respect to the utilization rate follows Baxter and Farr (2005) who pick a value of 1 that is also supported by empirical estimates in Basu and Kimball (1997).

Demographics and Inidividual Productivity. A household lives $T=240$ quarters and supplies labor in the first $T_{w}=160$ quarters. Moreover, the age-specific survival probabilities $\psi_{s}$ stem from Arias (2014) and describe the year 2010. The idiosyncratic productivity level is given by $e_{j}^{s}=z_{j} \bar{e}_{s}$. The age-specific component $\bar{e}_{s}$ denotes the average efficiency at age $s$ which is taken from Hansen (1993) and interpolated to in-between quarters. As a consequence, the model replicates the cross-section age distribution of earnings of the U.S. economy. With regard to the idiosyncratic component $z_{j}$, we follow Huggett (1996) and choose a log-normal dis- 
tribution of earnings for the youngest households with a variance equal to $\sigma_{z}^{2}=3.60$. This variance is chosen so that the Gini coefficients of labor income, gross market income, and wealth are close to the empirical values reported by Budría Rodriguez et al. (2002) that we describe in the next section.

We set the share of rule-of-thumb consumers $v_{R o T}$ equal to $43 \%$ which is in line with the estimates found in the literature. For example, Campbell and Mankiw (1989, 1991) provide empirical evidence that this parameter ranges between $35 \%$ and $50 \%$ in the United States. Furthermore, Shapiro and Slemrod (1995) find in a survey that $43 \%$ of consumers planned to spend most of the increase in disposable income with respect to the 1992 change in the standard income tax withholding amounts. ${ }^{16}$

Households. With respect to the preference parameters, we set the discount factor $\beta=1.003$ in order to match a risk-free interest rate on government bonds of $r^{b}=$ $4.0 \%$. The elasticity of marginal utility with respect to consumption is equal to $\eta=2$ and the parameter $\gamma_{0}$ is calibrated so that the average labor supply is equal to $33 \%$ of available time. The Frisch elasticity of labor supply is given by $1 / \gamma$. For example, MaCurdy (1981) and Altonij (1986) both use PSID data in order to estimate values of 0.23 and 0.28 , respectively, while Killingsworth (1983) finds an US labor supply elasticity equal to 0.4 . We will use the conservative estimate $1 / \gamma=0.2$ in accordance with Galí et al. (2007). Finally, we follow Uhlig (2007) and set the parameter $\mu$ governing the real wage rigidity in equation (8) equal to 0.8 .

Government. The share of government spending in GDP is set to $G / Y=20 \%$. The term $\rho_{g}$ regarding the first order auto-regressive process of government spending is equal to 0.87 and the standard deviation of innovations to government consumption amounts to $\sigma_{g}=0.016$ as in Schmitt-Grohé and Uribe (2007). For simplicity, we set the ratio of government debt to quarterly GDP equal to $B / Y=0 \%$. Moreover, we use a data-set provided by Gomme et al. (2011) in order to estimate the income tax parameters $\beta_{0}^{k}=0.20$ and $\beta_{1}^{k}=0.58$ using the observations from the period 1985-2008. We choose $\theta_{t r}=6.6 \%$ such that the income tax rates $\tau^{w}$ and $\tau^{k}$

\footnotetext{
${ }^{16}$ In Appendix A.3, we conduct a sensitivity analysis for the cases $v_{R o T}=0.35$ and $v_{R o T}=0.50$.
} 
match the corresponding average empirical values of $28 \%$ and $36 \%$, respectively. The tax rate on consumption is given by $\tau^{c}=0.05$ and, using OECD data, we choose $r e p=0.45$ in order to replicate the U.S. replacement ratio of pensions relative to average net wage earnings in the year 2014. With regard to the calibration of the dynamics of tax revenues and debt, we use parameter values provided by Galí et al. (2007) who estimate an elasticity of tax revenues with respect to government spending of $\omega_{g}=0.1$ that is close to the estimate in Blanchard and Perotti (2002). We also follow these authors and set the elasticity of taxes with respect to debt equal to $\omega_{b}=0.33$. Finally, the interest rate rule of the central bank satisfies the Taylor principle and we set the parameters $\phi_{m}$ and $\phi_{\pi}$ equal to 0.9 and 1.1 following Walsh $(2005)$.

\section{Steady State Behavior}

First, we describe the life-cycle behavior of Ricardian and rule-of-thumb households in steady state. Second, we present inequality measures of income and wealth. Third, we demonstrate that a rise in permanent government expenditures increase income inequality, but decreases wealth inequality in the long run in our model.

\subsection{Life-Cycle Profiles of Ricardian Households and Rule- of-Thumb Consumers}

Fig. 1 presents the steady-state behavior of Ricardian households and rule-of-thumb consumers over the life-cycle with respect to the productivity types $j \in\{1,2,3\}$. The profiles of consumption as displayed in the upper panels are hump-shaped. The consumption of Ricardians declines only in retirement after age $s=66$ and accords with empirical observations in its qualitative features. ${ }^{17}$ For the US economy,

\footnotetext{
${ }^{17}$ For the reader's convenience, we use the real life age in years rather than the quarterly age index $s$ in the figures hereinafter.
} 
Fernández-Villaverde and Krueger (2007) find that the empirical consumption-age profiles display a significant hump over the life cycle even after correcting for the change of the family size. For the high-education households (that are roughly corresponding to the high-productivity households in our model), the peak occurs at age 55, while the low-education households attain their consumption maximum at an earlier age close to 50 and the hump is much smaller. Therefore, in our model, the hump in consumption of the Ricardian households occurs somewhat too late in the life cycle. However, the consumption of rule-of-thumb consumers in the upper right panel drops earlier in life at age 51 so that total consumption of the different productivity types peaks much earlier in life in accordance with the aforementioned empirical evidence.

The profile of working hours of Ricardian households is depicted in the left panel of the second row. Their labor supply stays almost constant during the first 10 years and falls monotonously thereafter. This pattern is mainly driven by both the increasing wealth effect as agents build up savings for retirement and the humpshaped efficiency profile over the life cycle that is displayed in the lower right panel. In contrast, the labor supply of rule-of-thumb consumers does not fall substantially during working life because the wealth effect is absent. The panels in the third row display the gross market incomes of Ricardian households and rule-of-thumb consumers. These profiles follow a hump-shaped pattern and feature a kink after households enter retirement due to the absence of labor income. Moreover, this kink is more pronounced for rule-of-thumb consumers since Ricardian households receive an income stream from their savings during retirement. Finally, since pensions are below the wage income, all Ricardian households save for retirement and accumulate wealth until the last period of their working life as presented in the lower left panel.

\subsection{Inequality}

The heterogeneity with regard to individual productivity, $z_{j} \bar{e}_{s}$, and consumption type (Ricardian versus rule-of-thumb consumer) results in inequality of income and wealth among the households. The Gini coefficients of income and wealth amount 

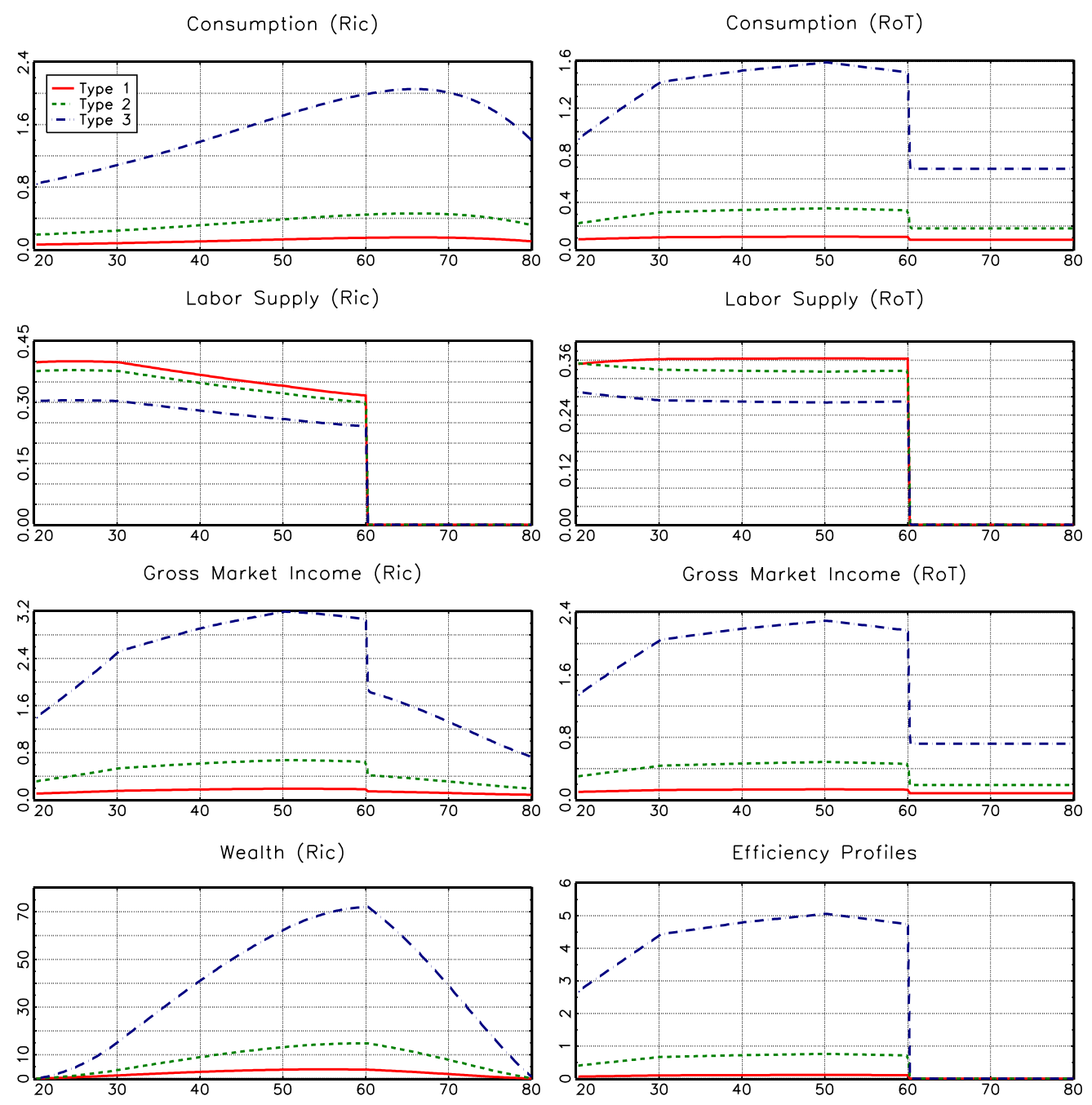

Figure 1: Steady-State Behavior of Ricardians (Ric) and Rule-of-Thumb Consumers (RoT). Abscissa: Age in years.

to 0.521 (net income after taxes), 0.543 (gross income before taxes), 0.631 (labor income), and 0.786 (wealth). Our inequality measures are very close to the empirical values. For example, Budría Rodriguez et al. (2002) report Gini coefficients of (gross) income, (gross) labor income and wealth that are equal to 0.553, 0.661 and 0.803 , respectively. ${ }^{18}$ Krueger et al. (2010) document the evolution of income and wealth

${ }^{18}$ Our model, however, falls short to replicate the high income and wealth shares of the top percentile for two reasons: 1) We do not consider self-employed workers and entrepreneurs. Quadrini (2000) presents empirical evidence that the concentration of income and wealth is higher among 
heterogeneity over time and notice that the inequality of earnings has increased in many countries, including the US, over the last three decades.

\subsection{Permanent Increase in Government Consumption}

How does a permanent increase of government consumption by 1 percentage point change the income and wealth distribution? In order to finance an increase of the government consumption-output ratio from $20 \%$ to $21 \%$, the government has to raise taxes. We assume that the consumption tax rate remains constant, while the labor and capital income tax rates, $\tau^{g}$ and $\tau^{k}$, rise from $28.1 \%$ to $29.4 \%$ and $35.9 \%$ to $36.6 \%$. As a consequence, the households earn less income and aggregate savings and capital fall. The income (and wealth) effect of lower net wages dominates the substitution effect and aggregate labor supply increases. The increase in effective labor supply is most pronounced among the high-productivity workers so that gross market income becomes more concentrated and the Gini coefficient increases by a small amount, from 0.5427 to 0.5431 .

In our comparative steady state analysis, we assume that the net replacement ratio remains constant at $45 \%$. Since net wages fall, the absolute level of pensions also decreases. Therefore, all Ricardian households spread out their savings over a longer time horizon so that the relative wealth of the retired Ricardian households increases. As a result, wealth inequality falls. The effect on the Gini coefficient of wealth is relatively small and it only declines from 0.7855 to 0.7850 .

entrepreneurs and that the introduction of an endogenous entrepreneurial choice in a dynamic general equilibrium model helps to reconcile the inequality in the model with that of the US economy. Cagetti and de Nardi (2009) introduce endogenous entrepreneurship in an OLG model. 2) We omit bequests. Among others, De Nardi and Yang (2016) set up a model that considers both bequests of wealth and inheritance of abilities from the parents and is able to match the skewness of the distribution of income, wealth, and bequests. See De Nardi (2015) for a survey of modeling wealth heterogeneity in quantitative general equilibrium models. 


\section{The Effects of a Government Spending Shock and Public Financing}

In this section, we present our main results on the effects of an unanticipated increase of government consumption. First, we present the responses of aggregate variables and show that, in accordance with the empirical and theoretical results of Galí et al. (2007), output, consumption, employment, and real wages increase, while investment declines. Second, we illustrate the responses of individual consumption, labor, and income and derive the result that income inequality increases, while wealth inequality declines. The change in inequality is quantitatively stronger if extra government expenditures are financed by debt rather than taxes. Third, we study welfare effects of government consumption shocks on lifetime utility and are able to distinguish households who favor tax financing from those who favor debt financing.

\subsection{Aggregate Variables}

Fig. 2 displays the impulse responses of aggregate variables to an increase of government consumption $G_{t}$ by one standard deviation. ${ }^{19}$ In particular, we have set the relative weights of government expenditures and debt to $\omega_{g}=0.1$ and $\omega_{b}=0.33$ in our fiscal rule (30) that describes the reaction function of tax revenues. We will refer to this case as "debt financing" which is illustrated in the upper panels of Fig. 2. In the bottom part of the figure, we compare it to the case of "tax financing", where we increase the reaction coefficient of taxes with respect to government expenditures $\omega_{g}$ from 0.1 to 0.9 .

A debt financed increase of government consumption in our New Keynesian model has the well-known effects on aggregate variables. Prices are sticky and when govern-

\footnotetext{
${ }^{19}$ Government debt is measured as a percentage deviation from steady state output, whereas the impulse responses of other variables are expressed as percentage deviations from their corresponding steady state levels.
} 
Debt Financing:
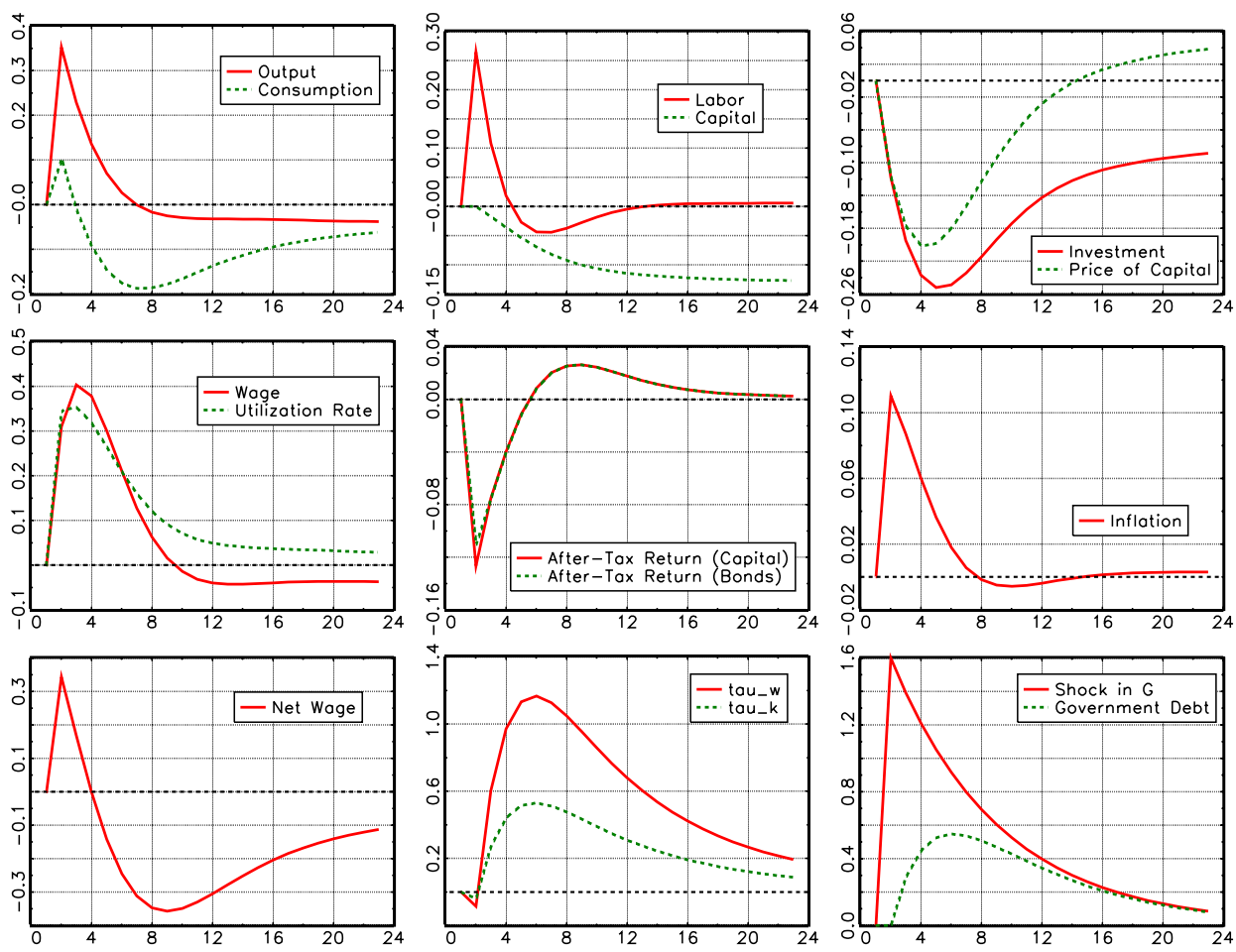

\section{Tax Financing:}
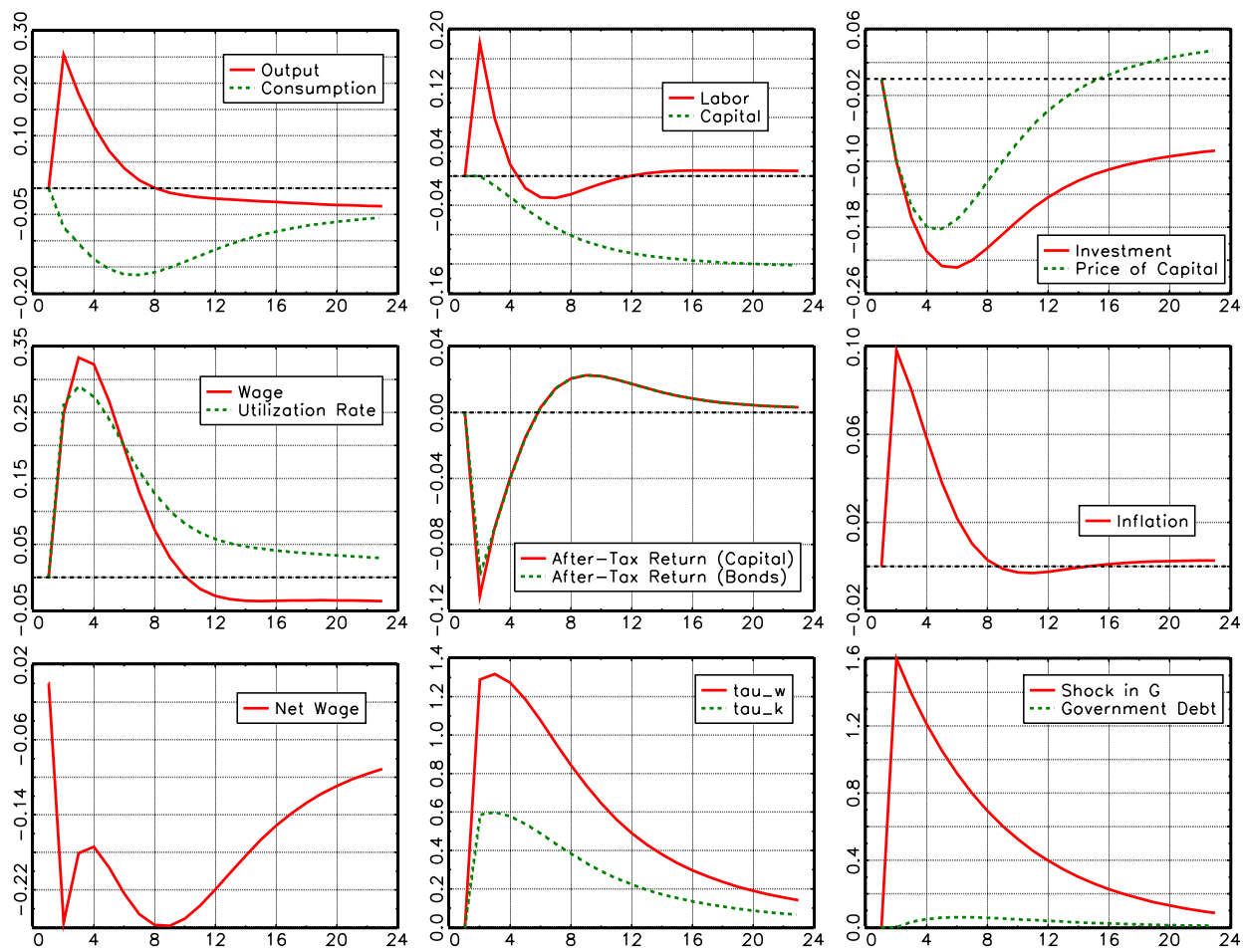

Figure 2: Impulse responses of aggregate variables under debt and tax financing (percent deviations). Abscissa: Periods after shock in $t=2$. 
ment demand increases, monopolistic firms increase production. As a consequence, output increases by $0.35 \%$ (see upper left panel in Fig. 2). In addition, government consumption crowds out capital since the government issues more bonds $B_{t}$ while investment $I_{t}$ declines. As a consequence, the price of capital $q_{t}$ falls from $-0.12 \%$ in period 2 to $-0.20 \%$ in period 4 and increases in the subsequent periods (see upper right panel). Ricardian households raise their labor supply (see middle panel in the upper row) because present and future tax increases constitute a negative wealth effect. In our model, this wealth effect is reinforced for Ricardian households with positive wealth because the price of capital $q_{t}$ and the (after tax) returns on both assets, capital and bonds, decline. Since prices are sticky and adjust only slowly, the mark-up falls and outweighs the effect of a lower marginal product of labor so that real wages (see left panel in the second row) increase in accordance with empirical evidence. ${ }^{20}$ While Ricardian households decrease consumption, rule-of-thumb consumers increase consumption so that aggregate private consumption increases. Moreover, the higher demand induces an increase in inflation and raises the utilization rate of capital. Government debt increases to $0.55 \%$ of stationary gdp until period 6 and declines afterwards as depicted in the right panel in the third row of Fig. 2. Therefore, taxes on labor and capital income increase slowly so that the initial positive response of the real net wage is reversed subsequently.

The lower panels in Fig. 2 illustrate the impulse responses for the case of higher tax financing. In this case, the qualitative responses are almost the same, but differ in size. As can be seen in the lower middle panel, labor income taxes $\tau_{t}^{w}$ (that are the sum of a payroll tax $\tau_{t}^{g}$ and social security contributions $\tau_{t}^{p}$ ) increase stronger on impact (by 1.29\%) since the government shifts the tax burden in the present. As a consequence, aggregate labor supply increases less and, hence, the output response is also smaller and only amounts to $0.25 \%$ in period 2 . Since the net market income of households is also lower due to higher taxes, aggregate private consumption decreases

\footnotetext{
${ }^{20}$ If we did not consider rule-of-thumb consumers, but only Ricardian households, real wages would fall because the labor supply response is stronger among the latter due of the wealth effect.
} 
by $0.08 \%$ in $t=2 .{ }^{21}$ The decline in the price of capital is also less pronounced. In particular, the price of capital $q_{t}$ drops from $-0.10 \%$ in period 2 to $-0.18 \%$ in period 5 and increases in the subsequent periods.

\subsection{Income and Wealth Inequality}

The individual impulse responses of labor supply, consumption, and savings depend on age $s$, the productivity type $j$, and the consumer type, Ricardian or rule-of-thumb consumer. For the benchmark case of debt financing, Fig. 3 illustrates the behavior of Ricardian households (first five panels) and rule-of-thumb consumers (last four panels) in the impact period $t=2$ when the shock occurs. Variables are expressed as absolute deviations from their steady-state value and are scaled by a factor of $100 .{ }^{22}$

When the shock hits the economy, the real net wage increases on impact. The substitution effect on labor supply dominates the income effect for rule-of-thumb consumers (see right panel in the second row in Fig. 3) wherefore they increase their labor supply. In contrast, the Ricardian households are also subject to an additional negative wealth effect so that their increase in labor supply is more pronounced (see left panel in the first row). Notice that the absolute change in labor supply is strongest among Ricardian households with little income who are characterized by the idiosyncratic productivity type $j=1$.

As a consequence of the higher wage and the increase in labor supply across all workers, the gross labor incomes of rule-of-thumb consumers and Ricardian households increase. However, as illustrated in Fig. 2, the real returns from both bonds and capital decline in period $t=2$ so that the total effect on the gross income of Ricardian households also depends on the individual's ratio of labor to capital. For

\footnotetext{
${ }^{21}$ The result is in accordance with the findings of Galí et al. (2007) who also finds a negative effect for this parameter value of $\omega_{g}$ in their Fig. 7 .

${ }^{22}$ If we had used percentage deviations instead, individuals with age-specific wealth close to zero would have displayed very large impulse responses.
} 
Labor Supply (Ric)
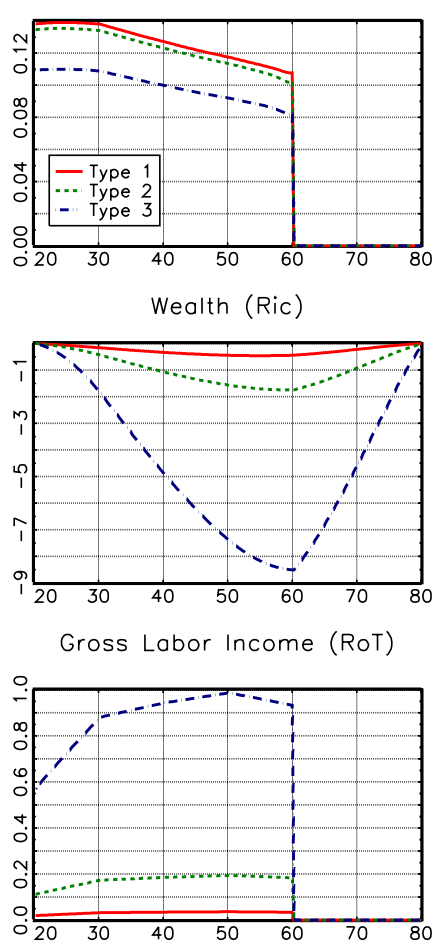

Gross Labor Income (Ric)
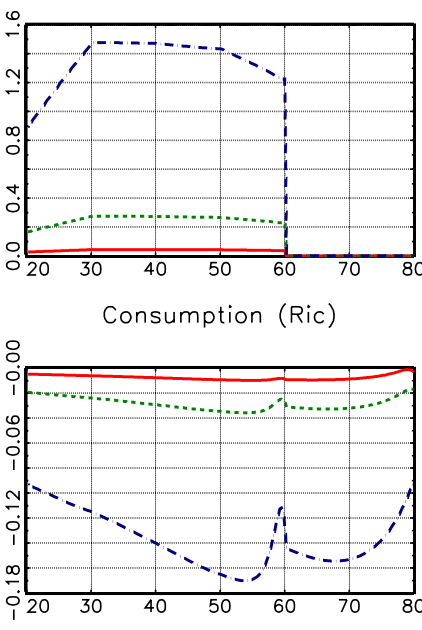

Gross Market Income (RoT)

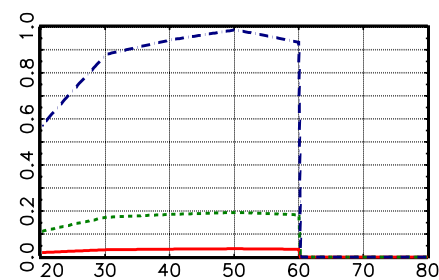

Gross Market Income (Ric)

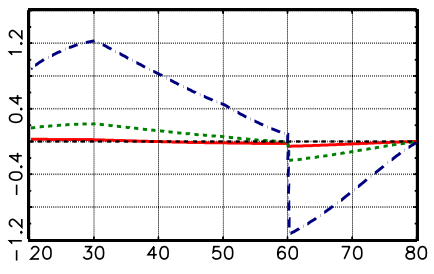

Labor Supply (RoT)

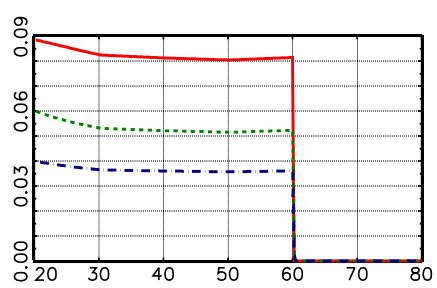

Consumption (RoT)

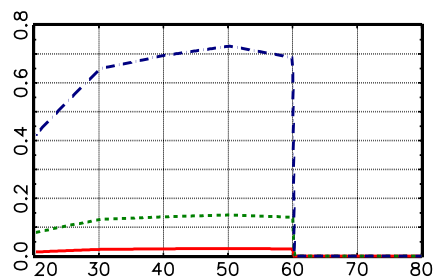

Figure 3: Cross-Section - Ricardian Households (Ric) \& Rule-of-Thumb Consumers $($ RoT) in $t=2$ (a.d. \& s.f.=100). Abscissa: Age in years.

the workers with productivity type $j \in\{2,3\}$ and household in the 20-40 age group with productivity type $j=1$, the increase in labor income dominates the decrease in capital returns so that their gross market income increases (see upper right panel in Fig. 3). In contrast, the gross market income of Ricardian retirees and older Ricardian workers described by productivity type $j=1$ falls. In addition, all Ricardian households experience a decline in wealth due to the declining price of capital $q_{t}$.

Fig. 4 presents the impulse responses of the Gini coefficient of gross income and wealth over time and the relative changes of the individuals' gross income and wealth in period $t=2$ when the shock hits the economy. The shaded lines in the top row depict the case of debt financing. On impact, the Gini coefficient of gross market income increases by a moderate amount equal to $0.029 \%$. Furthermore, the decline in the prices of capital $q_{t}$ reduces the wealth of Ricardian consumers so that wealth heterogeneity falls. However, the effects of an increase in government spending on 

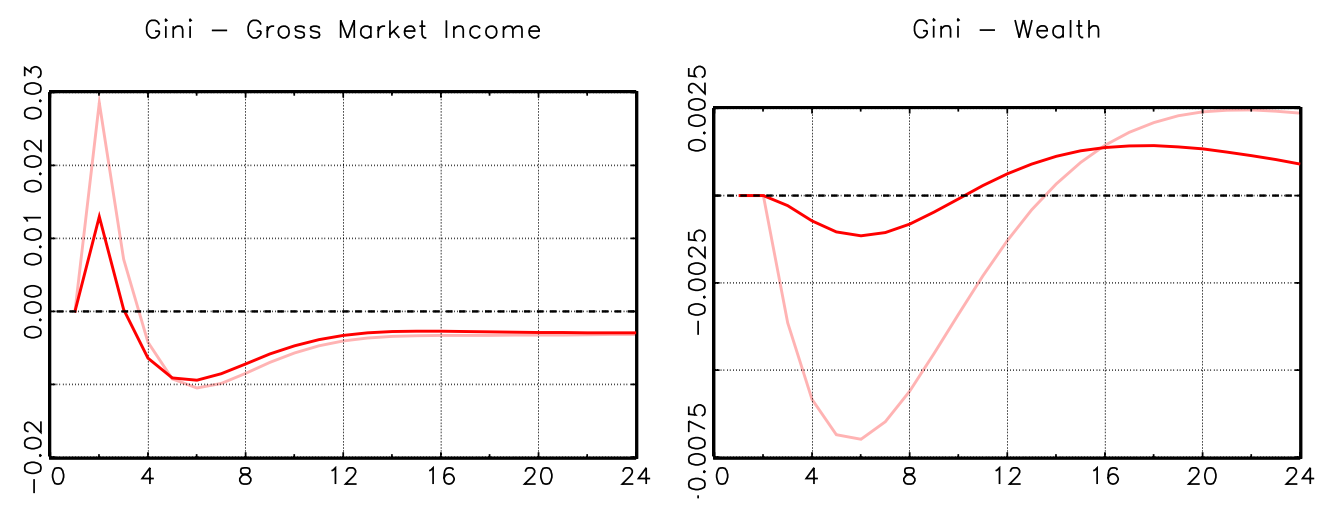

\section{Debt Financing:}

Gross Market Income (Ric)

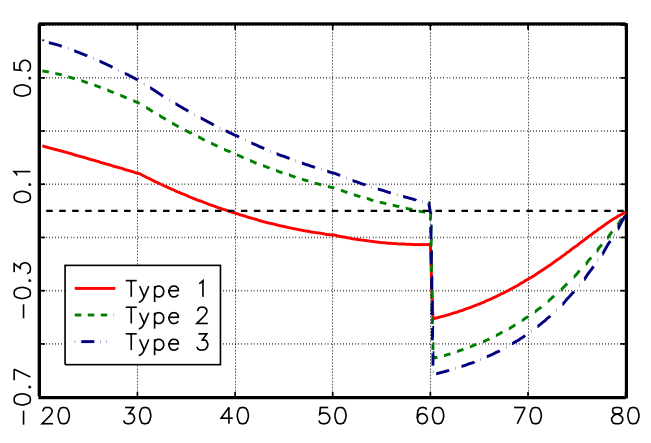

Gross Market Income (RoT)

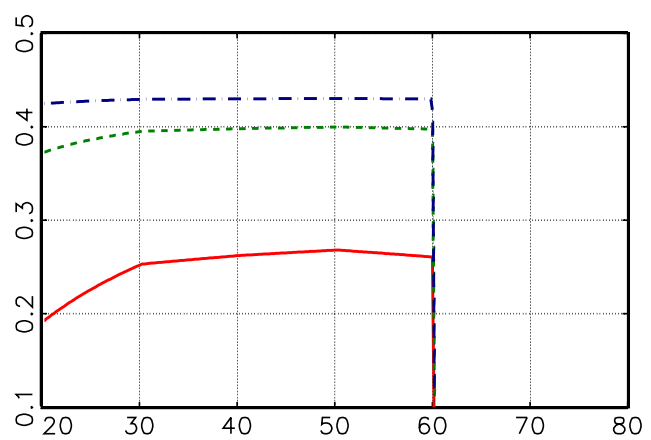

Tax Financing:

Gross Market Income (Ric)

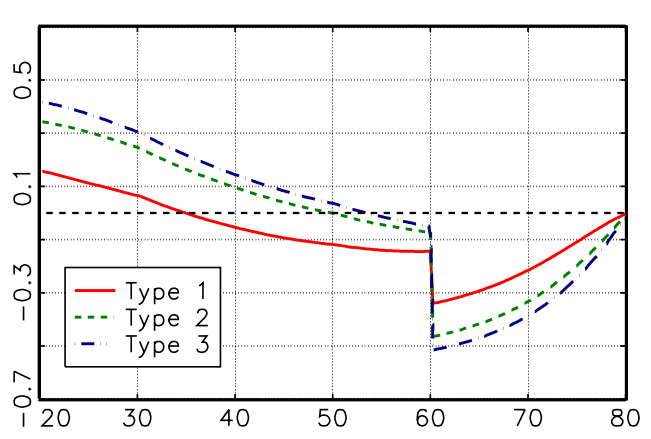

Gross Market Income (RoT)

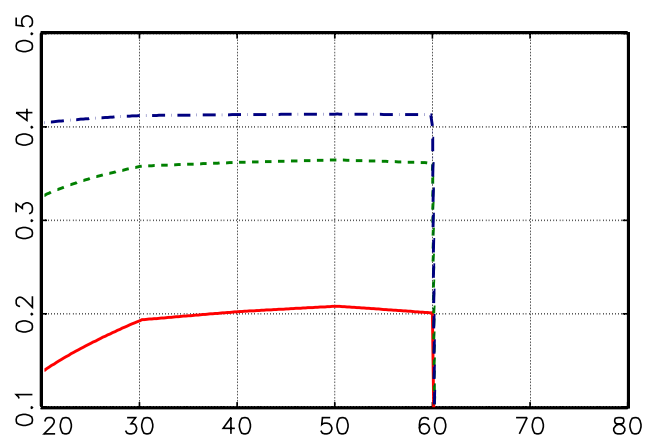

Figure 4: Impulse responses of Gini Coefficients (percent deviations) and Gross Market Income in $t=2$ (percent deviations) - Solid (shaded) lines $=$ tax-financed (bond-financed) increase in government spending. Abscissa - Gini Coefficients: Periods after shock in $t=2$. Abscissa - Gross Market Income: Age in years.

wealth inequality are rather negligible. The maximum impact occurs in period $t=6$, 
when the Gini coefficient of wealth decreases by approximately $0.007 \%$.

Notice that the Gini coefficient is an aggregate measure. Even though the response of the Gini coefficients of gross income is very small, the redistribution that takes place on the disaggregate level is nevertheless quantitatively significant. For example, in the case of debt financing (as displayed in the second row of Fig. 4), gross market income of the high-productivity Ricardian (RoT) households increases by $0.62 \%$ $(0.43 \%)$ for the 20 -year-old workers in period $t=2$, while it declines by $0.60 \%$ for the retired 60-year old Ricardian households. In particular, we observe that there is considerable redistribution among households with similar gross income. For example, some of the income-poor households increase their gross income, e.g. the low-productivity households at young age, while other income-poor households experience a decline in their gross income, e.g. the retired Ricardian households in old age. Similarly, there is considerable redistribution among the medium-income households as young workers with productivity $j \in\{2,3\}$ increase their income, while Ricardian retired households with high wealth (aged 60-70 years and with productivity $j=3$ ) receive smaller incomes. On the aggregate level, these various changes almost cancel.

In the case of tax financing (as presented by the solid lines in the top row of Fig. 4), the quantitative magnitude of the Gini impulse responses are smaller than in the case of bond financing. ${ }^{23}$ Since the responses of both net and gross wages are smaller than in the case of bond financing, e.g. the gross wage increases by only $0.25 \%$ rather than $0.31 \%$ in period $t=2$, labor market income rises less in relation to the constant pensions of retirees. In particular, the income of high-income households (the Ricardian households with high productivity $j=3$ and high wealth close to retirement age) reacts less strongly than in the case of bond financing so that the increase in income inequality is less pronounced and only amounts to $0.013 \%$ in period $t=2$. In addition, the effects on the Gini coefficient of wealth are negligibly small.

\footnotetext{
${ }^{23}$ The figures of the individuals' impulse responses for tax financing of additional government expenditures are presented in the Appendix A.2.
} 


\subsection{Welfare Effects}

In this section, we investigate the main question of our paper: Which households benefit from bonds rather than tax funding of additional government expenditures and which households lose? For this reason, we compute the (remaining) lifetime utility of all households at ages $s=1, \ldots, 240$ and distinguish between different productivity and consumer types. We compute the change in lifetime utility relative to that in steady state that results from an unanticipated shock to government consumption of one standard deviation in period $t=1$ and zero thereafter. Since government consumption $G_{t}$ is auto-correlated, $G_{t}$ adjusts only gradually to its steady state value as depicted in Fig. 2.

The absolute change of lifetime-utility is presented in the top row of Fig. 5. The case of bond (tax) financing is depicted by the shaded (solid) lines. For the Ricardian households, all productivity types experience a drop in lifetime utility irrespective of the financing form. In order to interpret utility changes, we computed the consumption equivalent change $c e c$ that is graphed in the bottom row. ${ }^{24}$ Welfare losses amount to $0.014 \%-0.113 \%$ of consumption depending on the individual's age when the shock occurs. Evidently, the young low-productivity households with $j \in\{1,2\}$ experience the highest drop in lifetime utility. In the period of the shock, labor of all Ricardian workers increases, while consumption of Ricardian households decreases for all ages (compare Fig. 3). Therefore, instantaneous utility in the period of the shock falls unanimously for all Ricardian households.

The effects of an unanticipated government consumption shock for the Rule-ofThumb consumers are illustrated on the right-hand side of Fig. 5. For both forms of government financing, the majority of households loses from extra government spending. Welfare losses are smaller than in the case of the Ricardian households and only amount to a maximum of $0.039 \%$ of consumption, while households close

\footnotetext{
${ }^{24}$ The consumption equivalent change is computed by the percentage number that steady-state consumption has to be changed so that the resulting lifetime utility (for given steady-state labor supply) is equal to the lifetime utility obtained in the case of a shock to government consumption.
} 

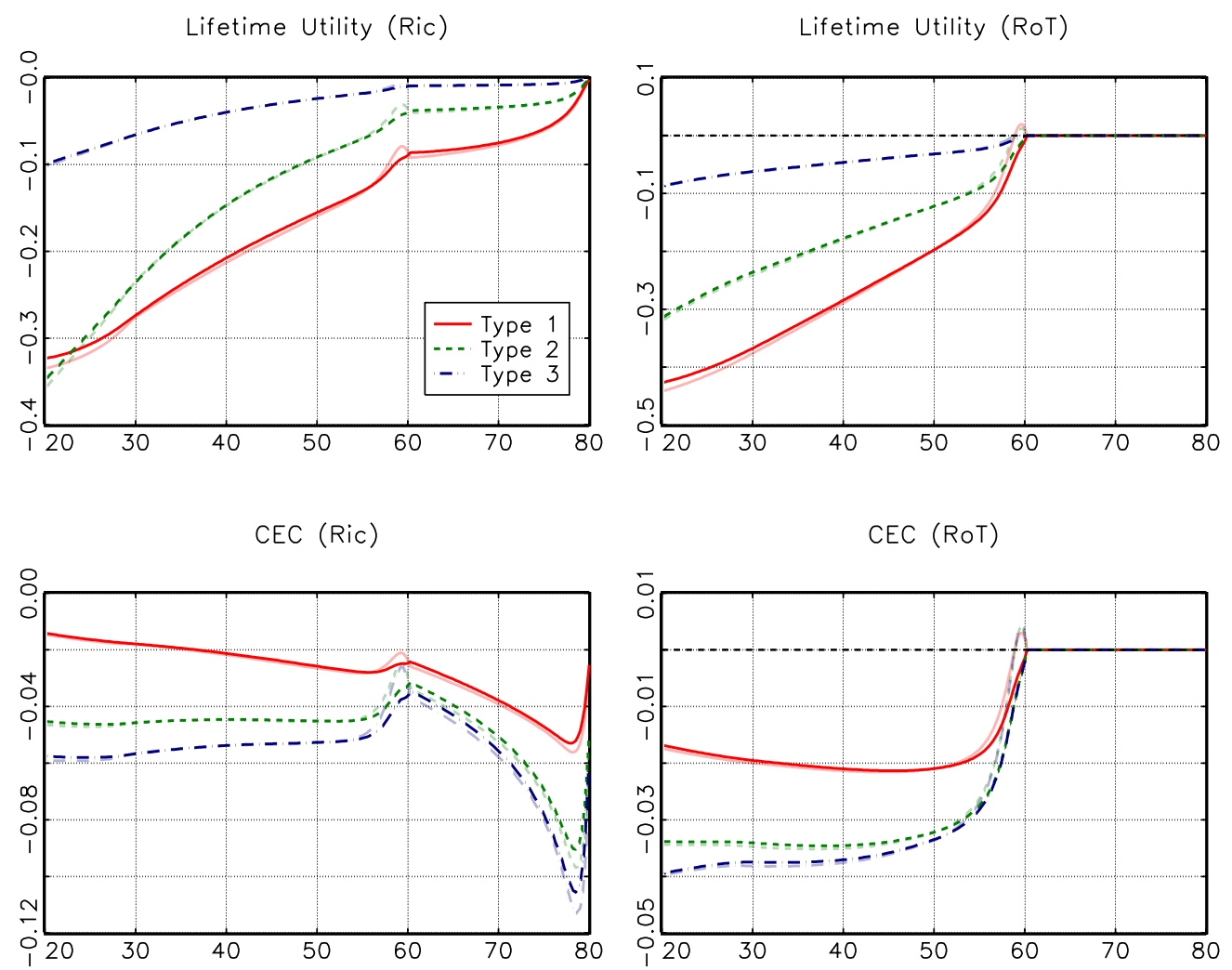

Figure 5: Lifetime Utility (a.d. \& s.f. $=100$ ) and Consumption Equivalent Change (CEC in \%) - Solid (shaded) lines = tax-financed (bond-financed) increase in government spending. The $\mathrm{x}$-axis denotes the age in years.

to retirement even benefit from debt-financed increase in government spending. The reason why rule-of-thumb households close to the retirement age of 60 years even experience an increase in welfare is presented by the instantaneous increase of net wages that occurs in the period of the shock. Higher net labor income raises consumption and instantaneous utility of the rule-of-thumb consumers. In the following periods $t=3,4, \ldots$, the net wage rate declines and falls below its steady-state value. If workers are close to retirement, however, they do not suffer as much from theses wage decreases because they receive constant pensions beyond the age of 60 years. We also observe that the welfare losses of the Ricardian households are mainly larger than those of the rule-of-thumb consumers because of the reduction in the price of capital and the temporary decline of asset returns.

In the case of tax financing (represented by the solid lines), welfare effects are more 
beneficial for all young workers and retired Ricardian households, while they are more detrimental for rule-of-thumb and Ricardian workers close to retirement. The retired rule-of-thumb households are indifferent between the two forms of government financing because we have assumed pensions to be constant. Hence, Ricardian retirees and younger workers favor tax funding of additional government expenditures, while both rule-of-thumb and Ricardian workers at real-life age around age 55-60 (years) advocate bonds financing. In particular, and contrary to conventional wisdom, even retired Ricardian household prefer higher tax funding because it entails smaller reductions in capital prices and, hence, in the value of their wealth. ${ }^{25}$

Our result that, to the best of our knowledge, has not been pointed out in the literature yet, is caused by the introduction of a variable price of capital $q_{t}$. The reaction of $q_{t}$ to higher government debt and crowding out of investment depends crucially on the elasticity $\zeta$ of adjustment costs $f(I / K)$ with respect to the investment-capital ratio $I / K$ according to (13a). We have calibrated the value $\zeta=1$ in line following Galí et al. (2007). The sensitivity of our results with respect to the elasticity $\zeta$ is illustrated in Fig. 6. For values $\zeta \in\{0.5,4.0\}$, our qualitative result that all Ricardian households except those close to retirement prefer tax financing is confirmed. Notice that the welfare losses from additional government expenditures increase with higher adjustment costs of capital and the upper limit almost amounts to $0.134 \%$ of consumption for a temporary increase in public consumption by one standard deviation. If we set $\zeta=0$ instead, all households face a constant price of capital. Thus, Ricardian households do not experience a drop in the value of their assets

\footnotetext{
${ }^{25}$ Notice that we have two non-Ricardian elements in our model so that Ricardian equivalence does not hold. On the one hand, we have rule-of-thumb consumers. On the other hand, lifetime is finite in our model and households are assumed not to be altruistic with respect to their children. As a consequence, they do not consider the loss in life-time utility of future generations that results from higher debt. The latter effect, however, is rather small in our model because we consider 240 periods and, according to Fig. 2, the real value of government debt under a debt-financed increase in government spending has already shrunk from the maximum deviation of $0.55 \%$ to $0.08 \%$ (of GDP) within the first 24 periods (=6 years) after the shock. Therefore, only the very old households can pass on some of the extra debt to yet unborn generations.
} 
and the contribution of higher taxes $\tau^{w}$ and $\tau^{r}$ on welfare becomes more important so that even retired Ricardian households prefer bond financing to tax financing of additional government expenditures.

$$
\zeta=4:
$$

CEC (Ric)

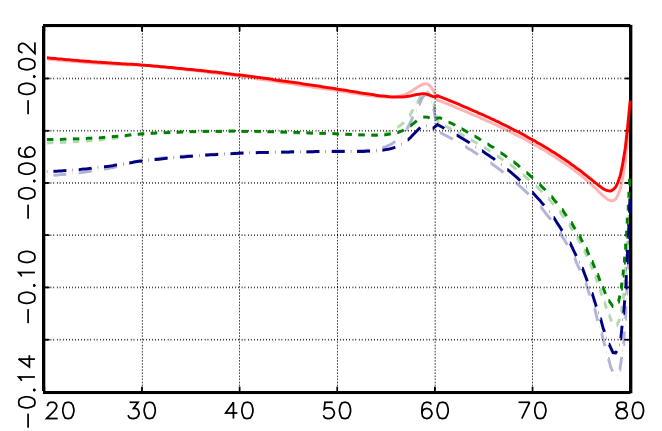

$\zeta=0.50$

CEC (Ric)

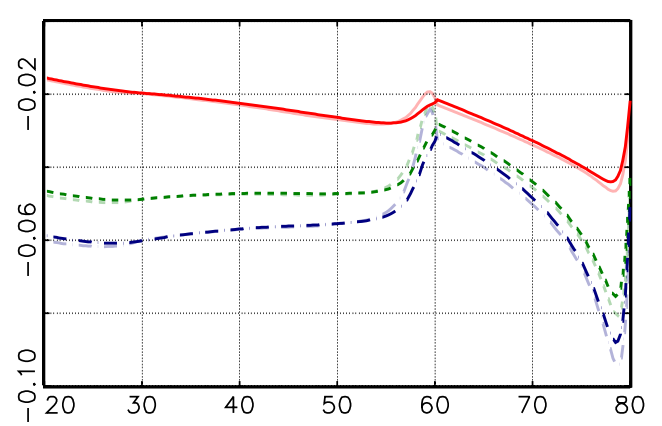

$\zeta=0$

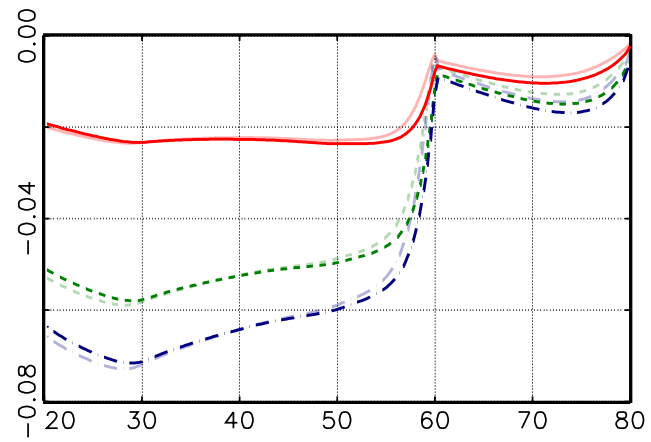

CEC (RoT)

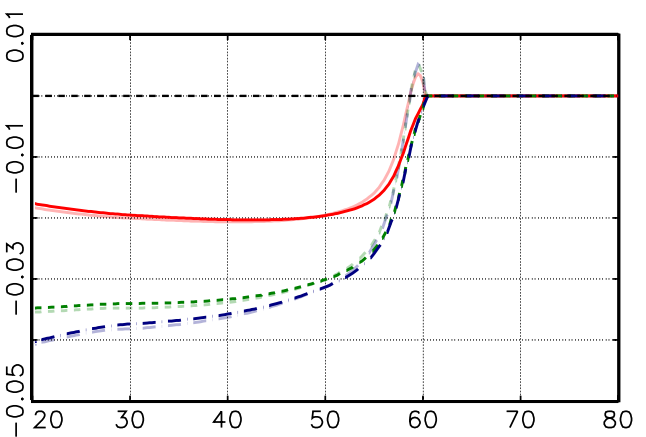

CEC (RoT)

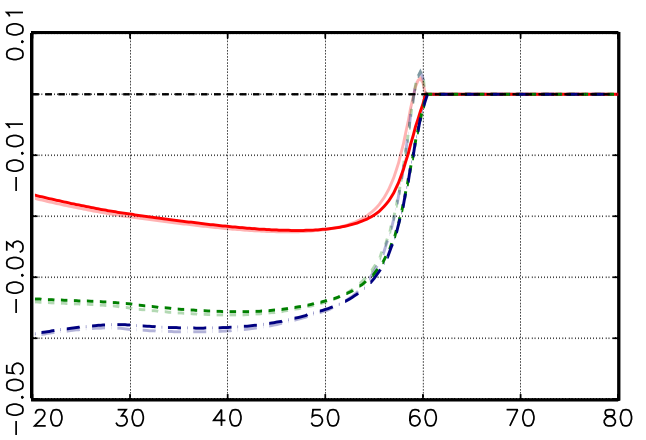

CEC (RoT)

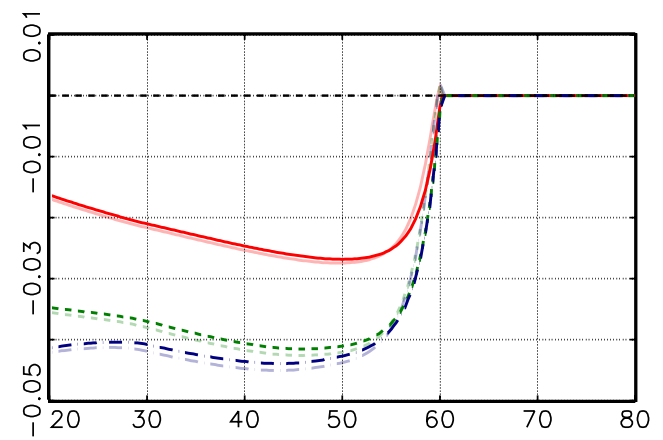

Figure 6: Sensitivity Analysis: Price of Capital. Consumption Equivalent Change (CEC in \%) - Solid (shaded) lines = tax-financed (bond-financed) increase in government spending. The $\mathrm{x}$-axis denotes the age in years. 


\section{Conclusion}

We have considered the distributional and welfare effects of unanticipated government spending in a heterogeneous-agent extension of the standard New Keynesian model with two types of households, a Ricardian and a rule-of-thumb consumer. In addition to the consumer type, households differ with resepct to age and individual productivity so that our Overlapping Generations model is able to replicate the inequality of income and wealth observed empirically in the US economy. Moreover, we have introduced a variable price of capital so that we are able to consider wealth effects that result from higher government debt. Our results are as follows.

First, the analysis shows that an unanticipated increase in government spending increases income inequality whereas the effects on wealth inequality are rather negligible. The quantitative effects are more noticeable if additional government expenditures are mainly financed by debt rather than taxes. In particular, an increase of one standard deviation in government consumption raises the Gini coefficient of gross market income by $0.029 \%$ in the former case and only by $0.013 \%$ in the latter case. Notice that, even though the magnitude of the redistributive effect seems small on first inspection of the Gini coefficients, one needs to bear in mind that the Gini coefficient is an aggregate measure and, in our study, dismantles significant redistribution on the disaggregate level. In particular, an unanticipated increase in government spending financed by higher debt induces a relative increase of gross market income of Ricardian workers and Rule-of-Thumb consumers by $-0.13 \%$ to $+0.64 \%$, while it decreases the gross income of Ricardian pensioners by $0 \%$ to $0.62 \%$. As these two effects almost cancel out on the aggregate level, the Gini coefficients display little changes.

Second, we have shown that welfare effects of higher unanticipated government consumption (by one standard deviation) are significant and particularly harm highproductivity households who experience, for example in the case of debt financing, welfare losses between $0.026 \%$ and $0.113 \%$ of lifetime consumption. In addition, the form of government financing has an effect on individuals' welfare. Contrary to conventional wisdom, not only the very young households, but also part of the old retired households prefer a tax financing over a debt-financing of expenditures.

One should, however, be careful to use the welfare results from our fiscal policy experiment for normative implications. In particular, we find that bond financing 
implies a somewhat higher response of inflation and wages to an increase of government consumption than tax financing. Therefore, the form of financing might have additional effects on the welfare of households that we did not consider in this paper. First, we only considered a proportional income tax. If the tax code were progressive and income tax brackets were only partially adjusted for inflation (or with a lag), households who end up in higher tax brackets might be affected more severely from bonds financing because (relatively) higher inflation pushes them into higher tax brackets. Second, we assumed pensions to be constant over the business cycle. If pensions were adjusted for higher wages, retirees might advocate for bond financing instead. Incorporating these elements in the present model constitutes an interesting direction for future research. 


\section{References}

Agnello, L. and R. M. Sousa (2013). Fiscal Policy And Asset Prices. Bulletin of Economic Research 65(2), $154-177$.

Altonij, J. G. (1986). Intertemporal Substitution in Labor Supply: Evidence from Micro Data. Journal of Political Economy 94(3), 176 - S215.

Arias, E. (2014). United States Life Tables, 2010. National vital statistics reports; vol 63 no 7. Hyattsville, MD: National Center for Health Statistics.

Basu, S. and M. S. Kimball (1997). Cyclical Productivity with Unobserved Input Variation. NBER working paper 5915.

Baxter, M. and D. D. Farr (2005). Variable Capital Utilization and International Business Cycles. Journal of International Economics 65(2), 335 - 347.

Blanchard, O. and J. Galí (2007). Real Wage Rigidities and the New Keynesian Model. Journal of Money, Credit and Banking 39(s1), 35 - 65.

Blanchard, O. and R. Perotti (2002). An Empirical Characterization of the Dynamic Effects of Changes in Government Spending and Taxes on Output. The Quarterly Journal of Economics 117(4), 1329 - 1368.

Bricker, J., L. J. Dettling, A. Henriques, J. W. Hsu, K. B. Moore, J. Sabelhaus, J. Thompson, and R. A. Windle (2012). Changes in U.S. Family Finances from 2007 to 2010: Evidence from the Survey of Consumer Finances. Federal Reserve Bulletin (June), $1-80$.

Brinca, P., H. H. Holter, P. Krusell, and L. Malafry (2016). Fiscal Multipliers in the 21st Century. Journal of Monetary Economics $77(\mathrm{C}), 53-69$.

Budría Rodriguez, S., J. Díaz-Giménez, V. Quadrini, and J.-V. Ríos-Rull (2002). Updated Facts on the U.S. Distributions of Earnings, Income, and Wealth. Federal Reserve Bank of Minneapolis - Quarterly Review.

Cagetti, M. and M. de Nardi (2009). Estate Taxation, Entrepreneurship, and Wealth. American Economic Review 99(1), 85 - 111.

Campbell, J. Y. and N. G. Mankiw (1989). Consumption, Income and Interest Rates: Reinterpreting the Time Series Evidence. In NBER Macroeconomics Annual 1989, Volume 4, NBER Chapters, pp. $185-246$. 
Campbell, J. Y. and N. G. Mankiw (1991). The Response of Consumption to Income: A Cross-country Investigation. European Economic Review 35(4), 723 - 756.

Christiano, L. J., M. Eichenbaum, and C. L. Evans (2005). Nominal Rigidities and the Dynamic Effects of a Shock to Monetary Policy. Journal of Political Economy 113(1), 1 - 45.

De Nardi, M. (2015). Quantitative Models of Wealth Inequality: A Survey. NBER working paper 21106.

De Nardi, M. and F. Yang (2016). Wealth inequality, Family Background, and Estate Taxation. Journal of Monetary Economics 77 (C), 130 - 145.

Fernández-Villaverde, J. and D. Krueger (2007). Consumption over the Life Cycle: Facts from Consumer Expenditure Survey Data. The Review of Economics and Statistics 89(3), $552-565$.

Galí, J., J. D. Lopez-Salido, and J. Vallés (2007). Understanding the Effects of Government Spending on Consumption. Journal of the European Economic Association 5(1), $227-270$.

Gomme, P., B. Rvaikumar, and P. Rupert (2011). The Return to Capital and the Business Cycle. Review of Economic Dynamics 14(2), 262 - 278.

Hansen, G. and S. İmrohoroğlu (2008). Consumption over the Life Cycle: The Role of Annuities. Review of Economic Dynamics 11(3), 566 - 583.

Hansen, G. D. (1993). The Cyclical and Secular Behaviour of the Labour Input: Comparing Efficiency Units and Hours Worked. Journal of Applied Econometrics $8(1), 71-80$.

Heer, B. and A. Maußner (2009). Dynamic General Equilibrium Modeling: Computational Methods and Applications (2nd ed.). Heidelberg: Springer.

Huggett, M. (1996). Wealth Distribution in Life-Cycle Economies. Journal of Monetary Economics 38(3), 469 - 494.

Killingsworth, M. R. (1983). Labor Supply. Cambridge, MA: Cambridge University Press.

Krueger, D., F. Perri, L. Pistaferri, and G. L. Violante (2010). Cross Sectional Facts for Macroeconomists. Review of Economic Dynamics 13(1), 1 - 14. 
MaCurdy, T. E. (1981). An Empirical Model of Labor Supply in a Life-Cycle Setting. Journal of Political Economy 89(6), 1059 - 85.

Monacelli, T., R. Perotti, and A. Trigari (2010). Unemployment Fiscal Multipliers. Journal of Monetary Economics 57(5), 531 - 553.

Quadrini, V. (2000). Entrepreneurship, Saving and Social Mobility. Review of Economic Dynamics 3(1), 1 - 40 .

Ravn, M. O., S. Schmitt-Grohé, and M. Uribe (2012). Consumption, government spending, and the real exchange rate. Journal of Monetary Economics 59(3), 215 -234 .

Rotemberg, J. J. and M. Woodford (1992). Oligopolistic Pricing and the Effects of Aggregate Demand on Economic Activity. Journal of Political Economy 100(6), $1153-1207$.

Schmitt-Grohé, S. and M. Uribe (2007). Optimal Simple and Implementable Monetary and Fiscal Rules. Journal of Monetary Economics 54(6), 1702 - 1725.

Shapiro, M. D. and J. Slemrod (1995). Consumer Response to the Timing of Income: Evidence from a Change in Tax Withholding. American Economic Review 85(1), $274-83$.

Uhlig, H. (2007). Explaining Asset Prices with External Habits and Wage Rigidities in a DSGE Model. American Economic Review 97(2), 239 - 243.

Walsh, C. E. (2005). Labor Market Search, Sticky Prices, and Interest Rate Policies. Review of Economic Dynamics 8(4), 829 - 849. 


\section{Appendix}

\section{A.1 Mathematical Derivations}

\section{A.1.1 Price Setting}

Firms choose their optimal nominal prices in a staggered fashion, according to Calvo (1983). There are two types of firms indexed by " $A$ " and " $N$ " in each period $t$. Type $A$ firms set their optimal relative price $\frac{P_{j, t}}{P_{t}}=\frac{P_{A, t}}{P_{t}}$ by solving an inter-temporal optimization problem, whereas type $N$ firms are only allowed to adjust their price in period $t$ according to a simple rule of thumb (7).

The probability of being a firm of type $A$ in period $t$ is given by $(1-\varphi)$. Hence, firms that are allowed to set their optimal price $\frac{P_{A t}}{P_{t}}$ in period $t$ solve a standard maximization problem: ${ }^{26}$

$$
\begin{aligned}
& \max _{P_{A t} / P_{t}} E_{t} \sum_{i=0}^{\infty} \varphi^{i} z_{t+i}\left[\left(\frac{\pi^{i} P_{A t}}{P_{t+i}}\right) Y_{A t+i}-g_{t+i}\left(Y_{A t+i}+F\right)\right] \\
& \text { s.t. } Y_{A t+i}=\left(\frac{\pi^{i} P_{A t+i}}{P_{t+i}}\right)^{-\epsilon} Y_{t+i},
\end{aligned}
$$

where the stochastic discount factor of the households $z_{t+i}$ is defined as

$$
z_{t+i} \equiv \frac{1}{\prod_{j=1}^{i}\left(R_{t+j-1}^{b} / \pi_{t+j}\right)} .
$$

We get, after some tedious algebra, the following first order condition:

$$
0=E_{t} \sum_{i=0}^{\infty} \varphi^{i} z_{t+i} Y_{j t+i}\left(\frac{\pi^{i}}{\prod_{j=1}^{i} \pi_{t+j}} \frac{P_{A t}}{P_{t}}-\frac{\epsilon}{\epsilon-1} g_{t+i}\right) .
$$

This condition states that the optimal relative price must be chosen in such a manner that discounted real marginal cost equal discounted real marginal revenues. Moreover, it can easily be shown that the term $\epsilon /(1-\epsilon)$ defines the gross price mark-up in a steady state with an inflation of zero. The realized (aggregate) profit $\Omega_{t}$ in period $t$ is given by

$$
\Omega_{t}=\int_{0}^{1}\left(\frac{P_{j t}}{P_{t}} Y_{j t}-w_{t} N_{j t}-r_{t} K_{j t}\right) d j=\int_{0}^{1}\left(\frac{P_{j t}}{P t} Y_{j t}-g_{t}\left(Y_{j t}+F\right)\right) d j,
$$

\footnotetext{
${ }^{26}$ Since all intermediate goods firms that are allowed to set their price optimally in period $t$ are identical, we can drop the firm index $j$ from the following equations.
} 
and the aggregate price level evolves according to the following equation:

$$
P_{t}^{1-\epsilon}=(1-\varphi) P_{A, t}^{1-\epsilon}+\varphi\left(\pi P_{t-1}\right)^{1-\epsilon} .
$$

Aggregate production $Y_{t}$ as presented in (2) and total production in the intermediate goods sector $\tilde{Y}_{t}$

$$
\tilde{Y}_{t}=N_{t}^{1-\alpha}\left(u_{t} K_{t}\right)^{\alpha}-F
$$

are related by the following equation:

$$
Y_{t}=\frac{1}{q_{t}^{p}} \tilde{Y}_{t}
$$

where $q_{t}^{p}$ measures the price dispersion in the intermediate goods sector and evolves according to the following dynamic equation:

$$
q_{t}^{p}=(1-\varphi)\left(\frac{P_{A t}}{P_{t}}\right)^{-\epsilon}+\varphi\left(\frac{\pi_{t}}{\pi}\right)^{\epsilon} q_{t-1}^{p}
$$

The first-order condition of this price-setting problem are presented by

$$
\frac{P_{A t}}{P_{t}} \cdot \Gamma_{2 t}=\frac{\epsilon}{\epsilon-1} \cdot \Gamma_{1 t}
$$

where

$$
\begin{aligned}
& \Gamma_{1 t}=g_{t} Y_{t}\left(\frac{P_{A t}}{P_{t}}\right)^{-\epsilon}+\varphi z_{t+1}\left(\frac{\pi\left(P_{A t} / P_{t}\right)}{\pi_{t+1}\left(P_{A t+1} / P_{t+1}\right)}\right)^{-\epsilon} \Gamma_{1 t+1}, \\
& \Gamma_{2 t}=Y_{t}\left(\frac{P_{A t}}{P_{t}}\right)^{-\epsilon}+\varphi z_{t+1}\left(\frac{P_{A t} / P_{t}}{P_{A t+1} / P_{t+1}}\right)^{-\epsilon}\left(\frac{\pi}{\pi_{t+1}}\right)^{1-\epsilon} \Gamma_{2 t+1} .
\end{aligned}
$$

In steady state, we assume that profits are equal to zero. Hence, the fixed cost $F$ is given by

$$
F=\frac{1-g}{g} Y,
$$

where marginal cost amount to

$$
g=\frac{\epsilon-1}{\epsilon} .
$$




\section{A.1.2 Capital Producers}

The production technology (11) implies

$$
\begin{aligned}
\frac{d \Omega_{t}^{c}}{d I_{t}} & =q_{t} K_{t} \frac{a_{1}(1-\zeta)}{1-\zeta}\left(\frac{I_{t}^{D}}{K_{t}}\right)^{-\zeta} \frac{1}{K_{t}}-1, \\
& \Rightarrow q_{t}=\frac{1}{a_{1}}\left(\frac{I_{t}^{D}}{K_{t}}\right)^{\zeta} . \\
\frac{d \Omega_{t}^{c}}{d K_{t}} & =q_{t}\left(\frac{a_{1}}{1-\zeta}\left(\frac{I_{t}^{D}}{K_{t}}\right)^{1-\zeta}+a_{2}\right)-r_{t}^{c}, \\
& \Rightarrow r_{t}^{c s}=q_{t}\left(\frac{a_{1} \zeta}{1-\zeta}\left(\frac{I_{t}}{K_{t}}\right)^{1-\zeta}+a_{2}\right) .
\end{aligned}
$$

Thus, profits are always equal to zero:

$$
\begin{aligned}
\Omega_{t}^{c} & =q_{t} f\left(I_{t}^{D} / K_{t}\right) K_{t}-I_{t}^{D}-r_{t}^{c s} K_{t}, \\
& =q_{t} f\left(I_{t}^{D} / K_{t}\right) K_{t}-I_{t}^{D}-q_{t}\left(f\left(I_{t}^{D} / K_{t}\right)-f^{\prime}\left(I_{t}^{D} / K_{t}\right) \frac{I_{t}^{D}}{K_{t}}\right) K_{t}, \\
& =q_{t} f\left(I_{t}^{D} / K_{t}\right) K_{t}-I_{t}^{D}-q_{t} f\left(I_{t}^{D} / K_{t}\right) K_{t}+I_{t}^{D}, \\
& =0 .
\end{aligned}
$$

In steady state, $q=1$ and $r^{c s}=0$ yield

$$
\begin{aligned}
& a_{1}=\delta^{\zeta}, \\
& a_{2}= \begin{cases}-\frac{\delta \zeta}{1-\zeta}, & \text { for } 1 \neq \zeta>0, \\
\delta-\ln \left(\delta^{\delta}\right), & \text { for } \zeta=1 .\end{cases}
\end{aligned}
$$

\section{A.1.3 Capital Utilization}

With $\delta\left(u_{t}\right)$ given by $(17)$ and the interest rate $r_{t}^{i s}$ from $(6 \mathrm{~b})$, the optimal utilization rate implied by the household's first-order condition (22e) is given by

$$
u_{t}=\left(\frac{\alpha g_{t}}{q_{t} \delta_{1}\left(1+\epsilon_{u}\right)}\left(\frac{K_{t}}{N_{t}}\right)^{\alpha-1}\right)^{1 /\left(1+\epsilon_{u}-\alpha\right)} .
$$

In steady state, $u=1$ and $\delta(1)=\delta$ imply

$$
\begin{aligned}
\delta_{1} & =\left(\frac{\alpha g}{q\left(1+\epsilon_{u}\right)}\right)\left(\frac{N}{K}\right)^{1-\alpha}, \\
\delta_{0} & =\delta-\delta_{1} .
\end{aligned}
$$




\section{A.2 Impulse Responses for a Tax-Financed Increase in Gov- ernment Spending}
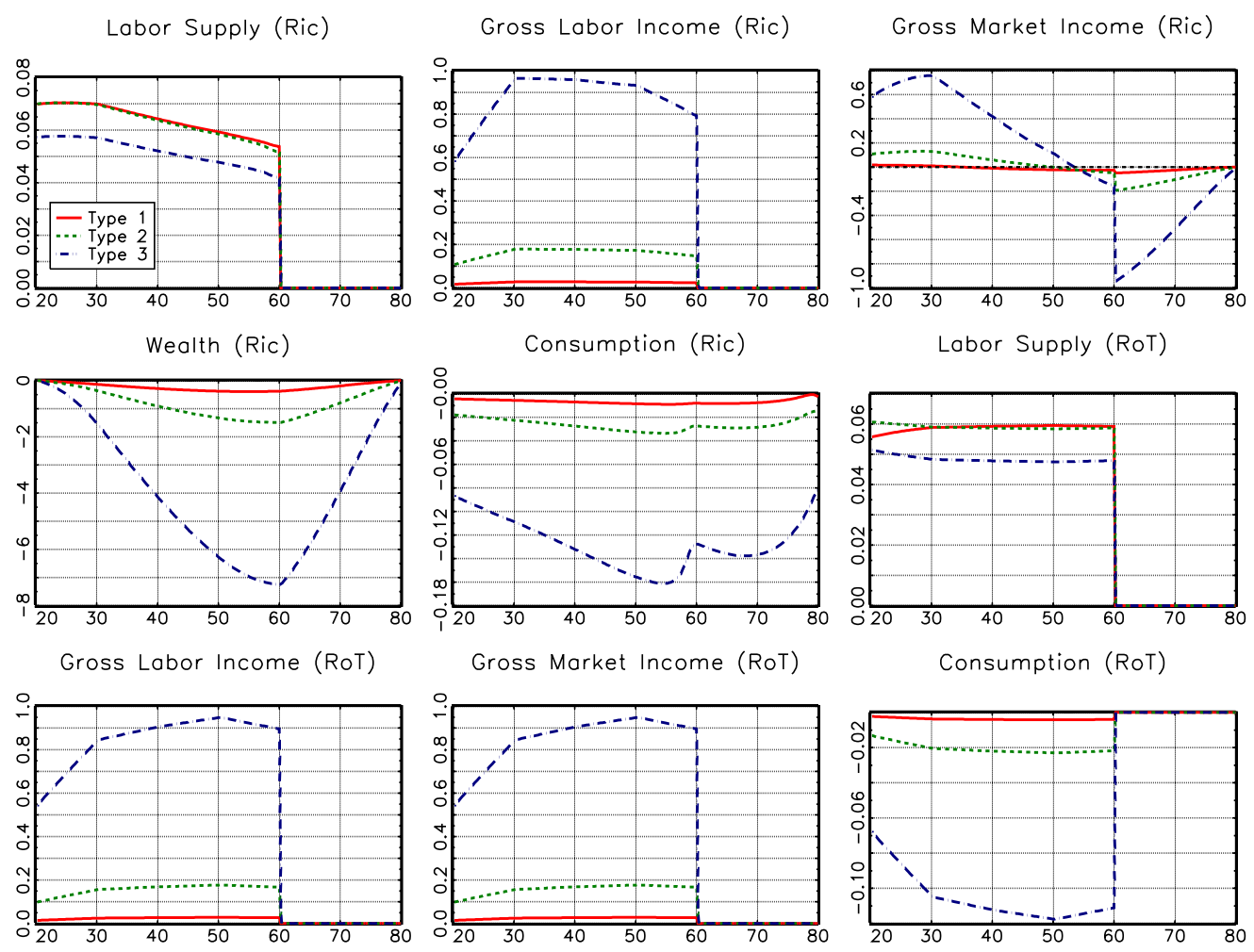

Figure A.1: Cross-Section - Ricardian Households (Ric) \& Rule-of-Thumb Consumers $(\mathrm{RoT})$ in $\mathrm{t}=2$ (a.d. \& s.f. $=100)$

\section{A.3 Sensitivity Analysis - RoT}

In this section, we conduct a sensitivity analysis of our welfare results with respect to the share of rule-of-thumb consumers $v_{R o T} \in\{0.5,0.35\}$. Fig. A.2 displays the change in individual welfare if there is a positive shock to government spending at the amount of one standard deviation $\sigma_{g}=0.016$. If the share of rule-of-thumb comsumers increases to $v_{R o T}=0.50$, our results are almost identical with respect to our benchmark case with $v_{R o T}=0.43$. Ricardian retirees also advocate tax financing, whereas Ricardian workers and rule of-thumb-consumers close to retirement still favor debt financing (see first row in Fig. A.2). Moreover, the corresponding differences in welfare between tax financing and debt financing are even more pronounced for retired Ricardian households and rule of thumb consumers close to retirement. The differences for the oldest Ricardian workers decline. In contrast, a lower share 
of rule-of-thumbers that is equal to $v_{R o T}=0.32$ increases the attraction of bond financing for old Ricardian workers, and Ricardian retirees become almost indifferent between both forms of government financing (see last row in Fig. A.2). The number of rule-of-thumb consumers favoring bond-financing declines.

$$
v_{R o T}=0.50 \text { : }
$$

CEC (Ric)

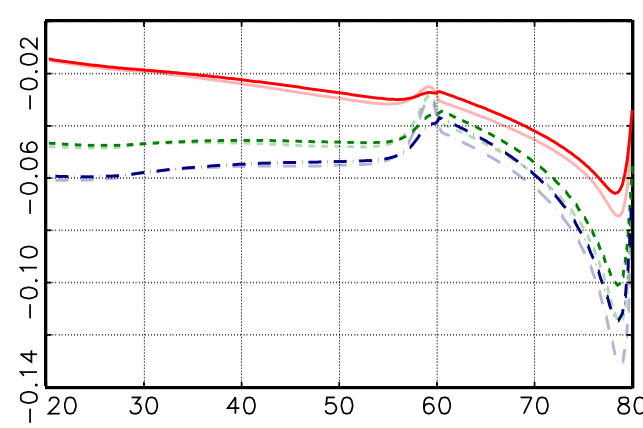

$v_{R o T}=0.35$

CEC (Ric)

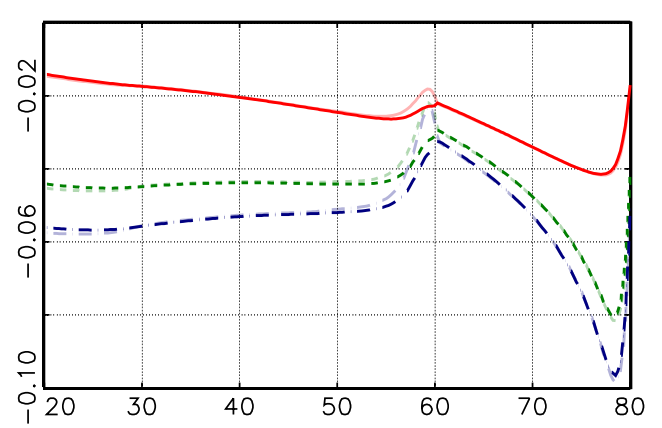

CEC (RoT)

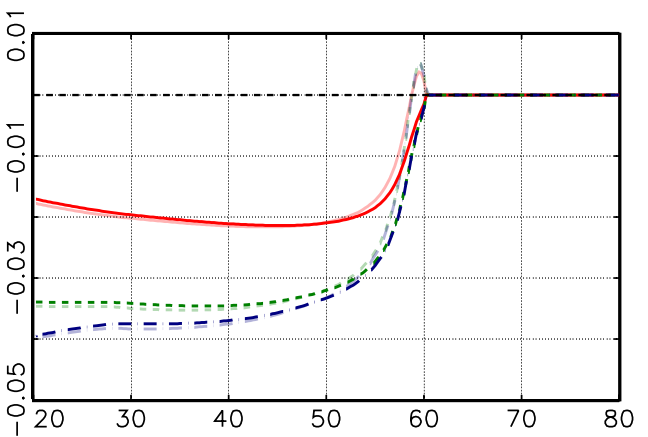

CEC (RoT)

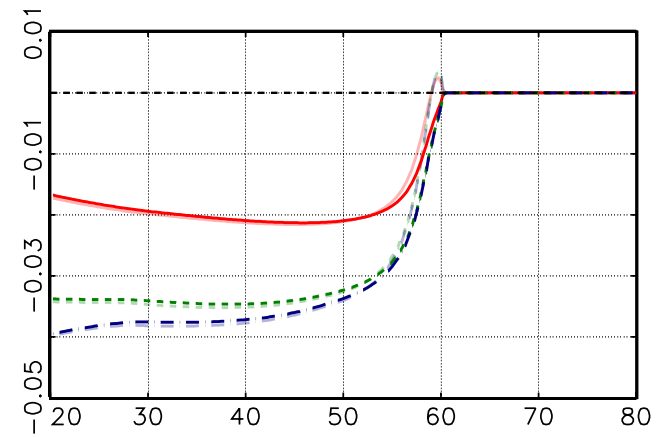

Figure A.2: Sensitivity Analysis: Share of Rule-of-Thumb Consumers. Consumption Equivalent Change (CEC in \%) - Solid (shaded) lines = tax-financed (bond-financed) increase in government spending. The $\mathrm{x}$-axis denotes the age in years. 


\section{A.4 U.S. tax rates on labor and capital income}

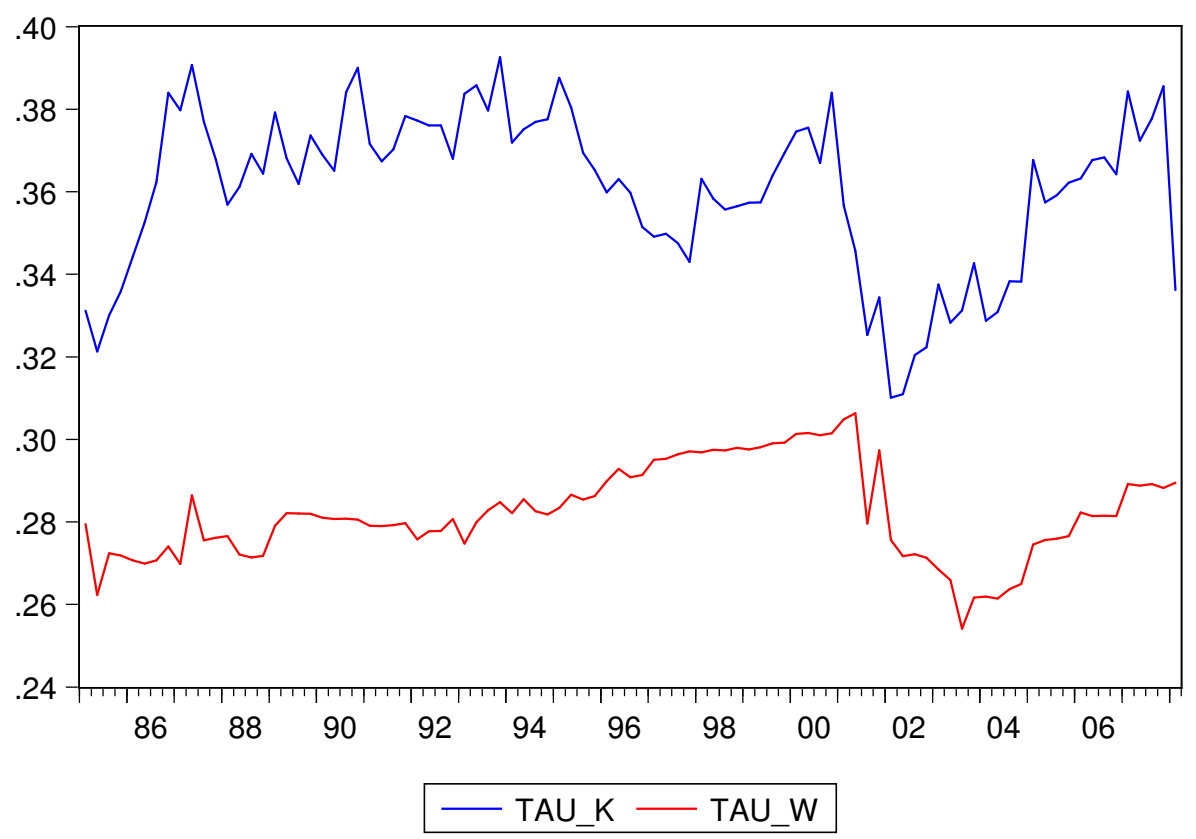

Figure A.3: U.S. Tax Rates on Labor (tau w) and Capital (tau k) Income. Source: Gomme et al. (2011). 